\title{
Thorax
}

\section{Multicentre evaluation of two multiplex PCR platforms for the rapid microbiological investigation of nosocomial pneumonia in UK ICUs: the INHALE WP1 study}

\begin{tabular}{|c|c|}
\hline Journal: & Thorax \\
\hline Manuscript ID & thoraxjnl-2021-216990.R2 \\
\hline Article Type: & Original research \\
\hline $\begin{array}{r}\text { Date Submitted by the } \\
\text { Author: }\end{array}$ & 12-Nov-2021 \\
\hline Complete List of Authors: & $\begin{array}{l}\text { Enne, Virve ; University College London } \\
\text { Aydin, Alp; University College London } \\
\text { Baldan, Rossella; University of East Anglia; King's College London } \\
\text { Owen, Dewi R; University College London } \\
\text { Richardson, Hollian; University of East Anglia } \\
\text { Ricciardi, Federico; University College London, Statistical Science } \\
\text { Russell , Charlotte; University of East Anglia Norwich Medical School } \\
\text { Nomamiukor-Ikeji, Brenda O.; University College London } \\
\text { Swart, Ann-Marie; University of East Anglia, Norwich Clinical Trials Unit } \\
\text { High, Juliet; University of East Anglia, Norwich Clinical Trials Unit } \\
\text { Colles, Antony; University of East Anglia, Norwich Clinical Trials Unit } \\
\text { Barber, Julie; University College London } \\
\text { Gant, Vanya; University College London Hospitals NHS Foundation Trust } \\
\text { Livermore, David; University of East Anglia Norwich Medical School } \\
\text { O'Grady, Justin; University of East Anglia Norwich Medical School; } \\
\text { Quadram Institute Bioscience, Norwich Research Park } \\
\text { INHALE WP1, Study Group; University College London }\end{array}$ \\
\hline Keywords: & Bacterial Infection, Critical Care, Pneumonia, Respiratory Infection \\
\hline
\end{tabular}

\section{SCHOLARONE Manuscripts}


I, the Submitting Author has the right to grant and does grant on behalf of all authors of the Work (as defined in the below author licence), an exclusive licence and/or a non-exclusive licence for contributions from authors who are: i) UK Crown employees; ii) where BMJ has agreed a CC-BY licence shall apply, and/or iii) in accordance with the terms applicable for US Federal Government officers or employees acting as part of their official duties; on a worldwide, perpetual, irrevocable, royalty-free basis to BMJ Publishing Group Ltd ("BMJ") its licensees and where the relevant Journal is co-owned by BMJ to the co-owners of the Journal, to publish the Work in this journal and any other BMJ products and to exploit all rights, as set out in our licence.

The Submitting Author accepts and understands that any supply made under these terms is made by BMJ to the Submitting Author unless you are acting as an employee on behalf of your employer or a postgraduate student of an affiliated institution which is paying any applicable article publishing charge ("APC") for Open Access articles. Where the Submitting Author wishes to make the Work available on an Open Access basis (and intends to pay the relevant APC), the terms of reuse of such Open Access shall be governed by a Creative Commons licence - details of these licences and which Creative Commons licence will apply to this Work are set out in our licence referred to above.

Other than as permitted in any relevant BMJ Author's Self Archiving Policies, I confirm this Work has not been accepted for publication elsewhere, is not being considered for publication elsewhere and does not duplicate material already published. I confirm all authors consent to publication of this Work and authorise the granting of this licence. 


\title{
Multicentre evaluation of two multiplex PCR platforms for the rapid microbiological investigation of nosocomial pneumonia in UK ICUs: the INHALE WP1 study
}

\author{
List of authors \\ Virve I Enne ${ }^{1}$, Alp Aydin 1, Rossella Baldan²,3, Dewi R Owen ${ }^{1}$, Hollian Richardson², Federico \\ Ricciardi $^{4}$, Charlotte Russell ${ }^{2}$, Brenda O. Nomamiukor-lkeji ${ }^{1}$, Ann Marie Swart ${ }^{5}$, Juliet High ${ }^{5}$, \\ Antony Colles ${ }^{5}$, Julie A Barber ${ }^{4}$, Vanya Gant ${ }^{6}$, David M Livermore ${ }^{2}$ and Justin O'Grady²,7 and the \\ INHALE WP1 Study Group*
}

\section{Authors affiliation}

${ }^{1}$ Centre for Clinical Microbiology, University College London, London, UK; ${ }^{2}$ Norwich Medical School, University of East Anglia, Norwich UK; ${ }^{3}$ Centre for Clinical Infection and Diagnostic Research, Kings College London, London, UK; ${ }^{4}$ Department of Statistical Science, University College London, London, UK; ${ }^{5}$ Norwich Clinical Trials Unit, University Of East Anglia, Norwich UK; ${ }^{6}$ Department of Microbiology University College London Hospitals, London UK ${ }^{7}$ Microbes in the Food Chain, Quadram Institute Bioscience, Norwich, UK

INHALE WP1 Study Group: Authors and their affiliations as above and Eleanor Tudtud BUPA Cromwell Hospital; Luke Moore, Nabeela Mughal and Suveer Singh, Chelsea and Westminster Hospital NHS Foundation Trust; Alistair Roy, City Hospitals Sunderland; Julian Sonksen, Dudley Group NHS Foundation Trust; Nigel Klein and Mark J. Peters, Great Ormond Street Hospital and UCL Great Ormond St Institute of Child Health NIHR Biomedical Research Centre; Meera Chand and Jonathan Edgeworth, Guy's and St Thomas' NHS Foundation Trust; Michael Karlikowski, James Paget University Hospitals NHS Foundation Trust; Christopher Parry and Ingeborg D. Welters, Liverpool University Hospitals NHS Foundation Trust; Ben Morton, Liverpool University Hospitals NHS Foundation Trust and Liverpool School of Tropical Medicine; Tim Leary, Parveez Moondi, Catherine Tremlett and Helen Williams, Norfolk and Norwich University Hospitals NHS Foundation Trust; Jeronimo Cuesta, North Middlesex Hospital; Mark Blunt, Queen Elizabeth Hospital Kings Lynn NHS Trust; Damien Mack and Daniel Martin, Royal Free Hospital; David Brealey, University College London Hospitals; Robert Horne and Laura Shallcross, University College London; David Turner, University of East Anglia and Nehal Patel, University Hospitals of North Midlands.

Corresponding author: Dr. V. I. Enne, Centre for Clinical Microbiology, University College London, $2^{\text {nd }}$ Floor, Royal Free Hospital, Rowland Hill Street, London NW3 2PF, UK; E-mail: v.enne@ucl.ac.uk 


\section{Present addresses:}

Alp Aydin, Quadram Institute Bioscience; Rossella Baldan, University of Bern; Brenda O.

Nomamiukor-Ikeji, St George's University of London; Dewi R Owen, King's College London;

Hollian Richardson, University of Dundee.

Keywords: hospital-acquired pneumonia, rapid diagnostics, PCR, antimicrobial stewardship 


\section{Summary \\ Background}

Culture-based microbiological investigation of hospital-acquired or ventilator-associated pneumonia (HAP or VAP) is insensitive, with aetiological agents often unidentified. This can lead excess antimicrobial treatment of patients with susceptible pathogens, whilst those with resistant bacteria are treated inadequately for prolonged periods. Using PCR to seek pathogens and their resistance genes directly from clinical samples may improve therapy and stewardship.

\section{Methods}

Surplus routine lower respiratory tract samples were collected from ICU patients about to receive new or changed antibiotics for hospital-onset lower respiratory tract infections at 15 UK hospitals. Testing was performed using the BioFire FilmArray Pneumonia Panel (bioMérieux) and Unyvero Pneumonia Panel (Curetis). Concordance analysis compared machine- and routine microbiology results, while Bayesian latent class $(B L C)$ analysis estimated the sensitivity and specificity of each test, incorporating information from both PCR panels and routine microbiology.

\section{Findings}

In 652 eligible samples; PCR identified pathogens in considerably more samples compared with routine microbiology: $60.4 \%$ and $74.2 \%$ for Unyvero and FilmArray respectively vs. $44.2 \%$ by routine microbiology. PCR tests also detected more pathogens per sample than routine microbiology. For common HAP/VAP pathogens, FilmArray had sensitivity of $91.7-100.0 \%$ and specificity of $87.5-99.5 \%$; Unyvero had sensitivity of $50.0-100.0 \% \%$, and specificity of $89.4-$ 99.0\%. BLC analysis indicated that, compared with PCR, routine microbiology had low sensitivity, ranging from $27.0 \%$ to $69.4 \%$.

\section{Interpretation}

Conventional and BLC analysis demonstrated that both platforms performed similarly and were considerably more sensitive than routine microbiology, detecting potential pathogens in patient samples reported as culture negative. The increased sensitivity of detection realised by PCR offers potential for improved antimicrobial prescribing. 
Key Messages

\section{What is the Key Question?}

How do the two currently-available automated PCR-based syndromic test systems perform in the microbiological diagnosis of hospital-acquired and ventilator-associated pneumonia (HAP/NAP) in critical care?

\section{What is the Bottom Line?}

Bayesian latent class analysis demonstrated that syndromic PCR-based diagnostic tests offer considerably improved sensitivity for the microbiological diagnosis of HAP and VAP compared with standard-of-care routine microbiological culture.

\section{Why Read On?}

The improved speed and sensitivity of PCR-based diagnosis of pneumonia has potential to optimise therapy of critically ill patients and to improve antibiotic stewardship. 


\section{Introduction}

Pneumonia is differentiated into its community-acquired (CAP), hospital-acquired (HAP) and ventilator-associated (VAP) forms. ${ }^{1}$ Even pre-COVID-19, it was the most-frequently-reported infection in intensive care unit (ICU) patients, ${ }^{2-4}$ with crude mortality estimated at $30-70 \%$ for nosocomial cases (i.e. HAP and VAP). ${ }^{2}$ Swift effective antimicrobial therapy after clinical onset is crucial to outcome, with increased mortality among patients receiving delayed antibiotics or those that prove inactive. 5,6

The bacteria, viruses and (rarely) fungi that cause nosocomial pneumonia cannot be distinguished from clinical symptomology. Rather, microbiological diagnosis is needed, delivering results in 48-72h and meaning that the patient must be treated empirically in the interim. EU, US and UK guidelines advocate broad-spectrum empirical antibiotics owing to the diversity of bacteria that can be responsible and the need to cover the resistances these may carry. ${ }^{2,4}$ 7,8 Aetiological investigation is by microbiological culture, hereafter termed routine microbiology, which depends upon cultivable bacteria being recoverable and fails to identify a pathogen in up to $50 \%$ of cases.$^{9-11}$ These patients nonetheless remain sick and mostly continue to receive empirical antibiotics.

The slowness and poor sensitivity of routine microbiology thus combine to promote poor stewardship and prolonged use of broad-spectrum agents, increasing the risk of side effects, including selection of resistant gut bacteria and Clostridium difficile. ${ }^{12} \mathrm{~A}$ further hazard, particularly in high-resistance countries, is that the empirical agent proves ineffective against the pathogen, increasing the risk of a poor clinical outcome.

Rapid, accurate, diagnostics provide a route to improving this situation, promoting early refinement of individual patients' therapy. Commercial "sample-in, answer-out" PCR-based pneumonia tests are now available, specifically the Unyvero (Curetis) and BioFire FilmArray (bioMérieux) platforms which have both received FDA-clearance for diagnosis of pneumonia. ${ }^{13}$ Both are substantially automated, seek prevalent pathogens and critical resistances and have turnaround times of hours instead of days. ${ }^{13-16}$ We evaluated and compared their performance, in respect of pathogen and resistance detection using lower respiratory tract samples from patients clinically diagnosed with HAP or VAP at 15 UK ICUs. As well as providing a manufacturer-independent direct comparison, we sought to choose one test to take forward into a randomized controlled trial (RCT), evaluating outcomes compared with patient management based on routine microbiology. This is now underway (Trial ID: ISRCTN16483855). ${ }^{17}$ Note that this study and RCT are distinct from a recently published trial for nebulised amikacin with the same name. ${ }^{18}$ 


\section{Materials and Methods}

Additional details and methods are described in supplementary data.

\section{Patients and specimens}

Between September 2016 and May 2018, surplus routine lower respiratory tract samples were collected from eligible patients with suspected HAP/VAP at the 15 participating ICUs. The sites represented a range of UK hospital types, included tertiary referral $(n=6)$, district general $(n=7)$, children's $(n=1)$ and private $(n=1)$.

Specimens were included if they had sufficient volume (>400 $\mu \mathrm{l})$ and were from patients hospitalized $\geq 48 \mathrm{~h}$ about to receive a new antibiotic or change in antibiotic for suspected lower respiratory tract infection. Specimens were eligible only when collected within $12 \mathrm{~h}$ (before or after) of antimicrobial therapy being initiated and then tested (or frozen at $-80^{\circ} \mathrm{C}$ ), within $72 \mathrm{~h}$ of collection. All lower respiratory specimen types were accepted, whereas upper respiratory tract specimens were excluded. Second specimens from the same patient were included only when collected $>14$ days after the first sample.

\section{Ethical approval}

This work had study-specific approval from the UK Health Research Authority (Reference: 16/HRA/3882, IRAS ID: 201977) and the UCL DNA Infection Bank Committee, whose operation is governed by the London Fulham Research Ethics Committee (REC Reference: 17/LO/1530).

\section{Routine microbiology}

Each respiratory specimen was initially cultured locally at the laboratory serving the participating hospital. Testing was according to their standard operating procedures (SOPs), all based on the Public Health England (PHE) UK Standard. ${ }^{19}$

\section{PCR Testing}

Samples were transported to two central research laboratories (University of East Anglia and University College London) by courier. Upon receipt, each was promptly tested using both the Unyvero Pneumonia Panel (Curetis, Holzgerlingen, Germany) and the BioFire FilmArray Pneumonia Panel (BioFire Diagnostics, Salt Lake City, USA) according to manufacturer's instructions. The tests are described in Table 1.

\section{Data Analysis}


Analyses were carried out using Stata ( $v 15)$ and R ( 3.5 or above), and followed a pre-defined, detailed statistical plan. Results from the conventional and PCR tests were described using standard summary statistics. Agreement between results was examined by categorising each sample in terms of concordance of organisms detected by PCR and routine microbiology, then calculating overall concordance with $95 \%$ Cls. Definitions of the categories are detailed in Table 2.

Sensitivity, specificity, positive predictive values (PPV) and negative predictive values (NPV) initially were estimated (with exact 95\% Cls) for each PCR target, taking routine microbiology and routine virology as the gold standard. Owing to concerns that routine microbiology provides a poor gold standard ${ }^{20}$ which could result in biased estimation of the diagnostic ability of PCR, estimates (with 95\% credible intervals) were also calculated using Bayesian Latent Class (BLC) models ${ }^{21,22,23}$ incorporating results from both PCR tests, and routine microbiology. BLC models do not assume the infallibility of any diagnostic test or combination thereof, instead estimating their accuracies based on the actual infection status (i.e., infected or not) of each patient. Models used non-informative priors for all parameters (although specificities were constrained to be above 0.15 to obtain more stable posterior distributions), and were fitted with and without assuming correlation between tests. The bestfitting models were identified based on Deviance Information Criteria.

\section{Scoring the Overall Performance of PCR-based Diagnostic Tests}

At the outset of the study, through expert consensus, a scoring system was developed to assess the suitability of each 'sample-in, answer-out' test for progression to the INHALE RCT. Tests were assessed against one essential criterion - that the incidence of major discordances, meaning failures to detect pathogens found by routine microbiology, must be $<5 \%$, and ten points-based 'Desirable Criteria', scoring a total of 150 (Table S1). Criteria i-iii were based on study results, criteria iv-viii on manufacturer's published information and criteria ix and $\mathrm{x}$ on a user questionnaire. The scale was weighted towards accurate detection of pathogens, with implementation-based criteria given a lower weighting.

\section{Role of the Funding Source}

The funder had no role in the study design, nor in the collection, analysis, and interpretation of data or in the writing of the report. The funder appointed an independent research Programme Steering Committee to provide quality assurance and oversight. Membership of the committee is 
listed on the study website (www.ucl.ac.uk/inhale-project/people).The corresponding author had full access to all study data and had final responsibility for the decision to submit for publication.

\section{Results}

\section{Specimens Collected}

A total of 752 samples, 652 of them eligible, were collected from the 15 participating ICUs (Figure 1). The range of eligible samples per site was 7-141, with 9 sites each providing $>20$ eligible samples. Most were from adults, with 72 from children; 260 were from patients with suspected HAP and 392 from patients with suspected VAP. Endotracheal aspirates $(n=299)$ were the most numerous sample type; followed by sputa (272 samples) BALs (44 samples) and non-directed BALs (23 samples), with 14 samples in the "other" or "unknown" category. A small majority of samples $(n=357)$ were collected before antibiotic administration.

\section{Routine Microbiology Results}

Routine microbiology was performed on all samples at the local laboratories. The median time to a result was $70.2 \mathrm{~h}$ (interquartile range (IQR) $51.1 \mathrm{~h}-92.1 \mathrm{~h}$ ), including a median of $6.1 \mathrm{~h}$ (IQR 2.5h-15.4h) transit time from the ICU to laboratory booking-in and 55.5h (IQR 44.8h-76.5h) from sample booking to release of results. The positivity rate was $44.2 \%$, with $35.1 \%$ recording one significant organism with $9.1 \%$ reporting two or more. The remaining $55.8 \%$ of samples were reported variously as 'normal flora', 'non-significant growth', or 'no growth'.

Staphylococcus aureus was the most-frequently-found bacterium (Figure 2), representing 23.6\% (83/352) of all organisms reported, followed by Pseudomonas aeruginosa (20.7\%); Enterobacterales collectively accounted for $38.1 \%$ of isolates, with Klebsiella spp. and Escherichia coli prominent (Figure 3a). Occasionally routine microbiology laboratories reported Candida spp., Enterococcus spp. and coagulase-negative staphylococci: these were excluded because there is no evidence base for their involvement in pneumonia. Table S2 lists the bacteria detected by all three methods in HAP compared with VAP patients.

Results of standard-of care diagnostic virology were recorded if was performed within $24 \mathrm{~h}$ of collection of the eligible bacteriology specimen. Only 113 patients, 33 of them children, had virology results meeting this criterion, and, of these, $31(27.4 \%)$ were positive: seven had influenza A, six adenovirus and six cytomegalovirus. The study was undertaken before SARSCoV2 began to circulate.

\section{PCR Results}


Among the 652 eligible samples, 631 had Unyvero tests and 632 had FilmArray tests within $72 \mathrm{~h}$ of the sample's collection, or with a frozen sample (Figure 1). Among these eligible tests, 620 generated a result on the FilmArray, whilst 12 failed. Defining failure on the Unyvero is more complex since targets are divided into eight chambers. We considered one sample where $>2$ chambers failed as a "total failure" along with 24 samples that failed to generate any result, leaving 606 valid results. In 32 of these 606 one or two chambers nonetheless failed. Their data were retained in the analysis, with the proviso that organisms sought by the failed chambers would have been missed. We did not note any user errors for either test; neither machine requires regular service or maintenance.

The overall positivity rate for both machines exceeded routine microbiology, at $60.4 \%$ for the Unyvero and $74.2 \%$ for the FilmArray (chi-square test: $p<0.0001$ ). Most specimens had multiple organisms detected (Figure 2), with this proportion higher for FilmArray than Unyvero. FilmArray found only bacteria in $54.2 \%$ of samples and only viruses in $6.9 \%$ whereas $13.1 \%$ contained both. The principal species detected by PCR, and their relative prevalence were broadly similar to routine microbiology, although $E$. coli and Klebsiella spp. were detected relatively more frequent by PCR, whereas $S$. aureus and $P$. aeruginosa were found less frequently (Figure $3 b$ ). Among viruses detected by the FilmArray, rhinovirus was the most prominent $(n=55)$, followed by influenza $A(n=29)$ and $B(n=25)$ (see Table S3); Unyvero does not seek viruses.

\section{Performance of PCR Tests}

Test performance was compared in several ways to accommodate the fact that routine microbiology is an imperfect 'gold standard' and the fact that the PCR tests seek multiple targets, more than one of which may be present in any sample, confounding simple calculation of overall sensitivity and specificity.

Overall test performance was first measured as concordance with routine microbiology, taken as a gold standard (Table 2). Both PCR tests deliver semi-quantitative outputs: the FilmArray reports bacterial targets as $10^{4}, 10^{5}, 10^{6}$ or $\geq 10^{7}$ copies per $\mathrm{ml}$, whereas the Unyvero reports as,+++ or +++ . In addition to detection at any concentrations, we therefore also undertook further concordance calculations, considering only targets detected at high concentration, defined as $10^{6}$ or $\geq 10^{7}$ copies $/ \mathrm{ml}$ for FilmArray and ++ or +++ for Unyvero (Table 2). Around half of the PCR results by each method demonstrated full positive or negative concordance with routine microbiology. Most of the remainder were either partially concordant or had minor discordance. Major discordance was rare, totalling only $4.6 \%$ for Unyvero and 
$1.8 \%$ for FilmArray. Details of results that were discordant between routine microbiology and PCR are shown in Tables S4 and S5. If PCR detections at low concentrations were excluded, full concordance increased for both tests, but major discordance increased unacceptably. A comparison of negative results determined that there was no significant difference in the number of positive PCR detections between samples reported in routine microbiology as "no growth" and "no significant growth" compared with those reported as "normal flora" and "mixed growth" (data not shown). The number of organisms detected per sample did not vary significantly according to sample type (Table S6).

PCR assay sensitivity was $>95 \%$ for most target bacteria, with NPVs $>98 \%$ (Table 3 ). Specificity and PPVs were lower, due to the PCR tests detecting more organisms per sample and finding more positive samples than routine microbiology. Strikingly, however, both machines often found the same organism as each other when routine microbiology failed to record any organism, casting doubt on routine microbiology as a gold standard. Accordingly, Table 4 shows performance estimates obtained from BLC models that make no presumption of one method being the reference. Based on this analysis, routine microbiology was the least sensitive technique, with sensitivity values for individual pathogens ranging from $27.1 \%$ to $68.7 \%$. In contrast, sensitivity values for the PCR tests remained high; FilmArray sensitivity ranged from $89.4 \%$ to $99.3 \%$ versus $83.9 \%$ to $96.9 \%$ (expect $K$. aerogenes, $48.4 \%$ ) for Unyvero. Specificity and PPV values for both PCR tests increased considerably compared with the values calculated using routine microbiology as a gold standard: in particular, specificity exceeded $99 \%$ for Unyvero targets and ranged from $93.9 \%$ to $99.9 \%$ for FilmArray targets. The PPV range was $62.1 \%$ to $99.3 \%$ for Unyvero and $56.1 \%$ to $96.6 \%$ for FilmArray. This BLC analysis omits data from 16S rRNA testing, also performed, as this technique could not distinguish species within several key genera, including Streptococcus and Klebsiella, reducing granularity. BLC analysis including 16 S data is included as Table S9; its numbers differ slightly from Table 4 but support the same conclusions.

We further conducted sub-analyses to investigate factors that might influence the results, such as the timing of the sample in relation to antibiotic administration, fresh vs. frozen samples, or time from sample collection to testing $(24 \mathrm{~h}, 48 \mathrm{~h}$ or $72 \mathrm{~h})$. None of these factors had a significant impact on the performance of the PCR tests (Tables S10, S1 and data not shown). Chlamydophila pneumoniae, Legionella pneumophila and Mycoplasma pneumoniae were excluded from analysis because they are not ordinarily sought by routine microbiology. Unyvero and FilmArray each detected M. pneumoniae once, in the same specimen, from participating sites where it was not sought by local microbiology. Unyvero detected two samples 
with L. pneumoniae; FilmArray and routine microbiology found none. C. pneumophila was not found by any method. Virology performance is shown in Table S3 for FilmArray only since Unyvero did not seek viruses; confidence intervals are wide due to the small number of routine results available for comparison.

\section{Antimicrobial Resistance and comprehensive culture}

All routine microbiology results for antimicrobial susceptibility testing were recorded, and Table S12 shows data for antimicrobials commonly used to treat HAP and VAP against prevalent species. The PCR tests differ from routine microbiology by seeking resistance (as genes) in a whole sample, not in particular bacteria. Assessment of the machines' performance in respect of resistance gene detection is further complicated because routine microbiology often reported no organism for PCR-positive samples. In other cases, we were unable to retrieve routine isolates for genetic investigation. These isolates were supplemented with those recovered by "comprehensive culture" on a sub-set of the discrepant samples (Supplementary methods). In total, comprehensive culture detected 12 additional key resistance genes, the host bacteria of which were not isolated or reported by routine microbiology (Table 5).

Specific resistance gene detections are catalogued in Table S13. We performed concordance analysis for 'high-consequence' resistance genes only, encoding extendedspectrum $\beta$-lactamases (ESBLs), carbapenemases or methicillin-resistant Staphylococcus aureus (MRSA) phenotypes. Among 17 Enterobacterales with ESBL phenotypes, 12 were from specimens where Unyvero found $b / a_{\mathrm{CTX}-\mathrm{M}}$ and 17 from those where FilmArray found $b / a_{\mathrm{CTX}}$ M. Considered from the opposite perspective, culture found ESBL producers in 12/14 cases where Unyvero found $b / a_{\text {CTX-M }}$ and $17 / 32$ cases where FilmArray did so. Fifteen cultured $S$. aureus isolates had an MRSA phenotype, of these 13 were from specimens where Unyvero found $m e c A / C$ and all 15 from those where FilmArray found mecA/C-MREJ. Considered from the opposite perspective, culture found MRSA in 13/25 cases where Unyvero found mecA/C in presence of $S$. aureus and 15/32 cases where FilmArray did so. There were only 11 detections of carbapenemase producers by Unyvero (including Acinetobacter OXA enzymes) and three by FilmArray, precluding review by enzyme type: culture confirmed a carbapenemase producer in 7/11 samples where Unyvero found a carbapenemase gene and 2/3 where FilmArray did so. Unyvero found a carbapenemase gene in all eight samples that grew an organism with carbapenemase phenotype, whilst FilmArray only found two carbapenamses in these isolates. (Table 5). 
Overall, comprehensive culture was performed on 103 samples, from which 123 potential pathogens were grown. Routine microbiology reported 65 potential pathogens from the same samples. Of the additional pathogens grown by comprehensive culture, $86 \%$ were also identified by one or both PCR tests.

\section{Overall Comparison of PCR Tests}

Both PCR systems met the essential requirement of having $<5 \%$ major discordances. Accordingly, we collated performance and implementability data in order to choose which to carry forward to the INHALE RCT. Our scoring (Table S1 and Table 6) weighted performance, but also considered ease-of-use, footprint, turnaround time and overall user experience.

FilmArray scored 105 points versus 68 for Unyvero. Unyvero was more concordant with routine microbiology ${ }_{2}$ but FilmArray had better sensitivity; Unyvero had a broader target panel but more failed tests. FilmArray performed better on characteristics relating to implementation, ease-of-use, turnaround time and user experience. Accordingly, we have preferred the FilmArray Pneumonia Panel for the INHALE RCT, now being undertaken across 12 UK ICUs.

\section{Discussion}

We undertook a comprehensive, independent, head-to-head comparison of the two currently available rapid tests for the microbiological investigation of pneumonia. Samples were from ICU patients for whom clinicians prescribed antimicrobials to treat pneumonia.

Both systems were considerably faster than routine microbiology and detected more organisms. This underscores the known poor sensitivity of routine microbiology in pneumonia. ${ }^{9-}$ ${ }^{11}$ Crucially, PCR tests tended to detect the same additional organisms in a given sample, implying that these additional detections were 'real' and that PCR may improve microbiological diagnosis of ICU pneumonia, increasing the proportion of patients who potentially could receive targeted antimicrobials. Furthermore, we perfromed comprehensive culture on A confounder is that, unlike the molecular tests, routine microbiology was decentralised, performed across 11 different hospital laboratories, receiving specimens from the 15 ICUs. The main difference between the two PCR tests is that Unyvero seeks S. maltophilia whereas FilmArray seeks respiratory viruses as well as bacteria. Early detection of $S$. maltophila might lead to early tailored therapy with co-trimoxazole, whereas fast viral detection may prompt the early cessation or de-escalation of antibiotic therapy.

To analyse test performance, we initially took routine microbiology as a gold standard. Only $56.6 \%$ of Unyvero results and $50.3 \%$ of FilmArray results were fully concordant with 
routine microbiology, with the remaining partial concordances and minor discordances mostly reflecting additional organisms detected by PCR, reflecting increased sensitivity of the latter. Per pathogen sensitivity performance was consistently good (91.7 to 100\%) for FilmArray; Unyvero's performance was more variable, with sensitivity $<90 \%$ for several pathogens. Cases where pathogens represented on the PCR panels were missed by these tests but found by routine microbiology were rare at $4.6 \%$ for Unyvero and $1.8 \%$ for FilmArray. Sensitivity and specificity values are similar to those reported by others in evaluations of one or other of the two PCR tests. ${ }^{15,16,24-27}$

We initially hoped that $16 \mathrm{~S}$ rRNA analysis could act as an alternative, molecular, reference, but it proved less sensitive than PCR and was abandoned (See Supplementary methods and data). Instead, the widely acknowledged limitations of routine microbiological culture $^{20}$ - confirmed by the frequency with which both PCR tests detected the same organism that was missed by routine microbiology - led us to adopt BLC analysis. In brief, this technique uses information from all tests to infer a new, unmeasurable yet underlying (i.e., latent) gold standard result, with no prior assumption about any one test being 'correct'. This method has been recommended and frequently adopted for studies evaluating diagnostics in settings where reference tests are acknowledged to be sub-optimal. $21,22,28,29$ BLC analysis showed (i) the sensitivity of routine microbiology was extremely poor and (ii) the specificity and PPV of the PCR tests were considerably higher than those calculated using routine microbiology as the "gold" standard. This suggests that both PCR tests were clearly superior to routine microbiology, and that the latter should perhaps not be considered a gold standard technique. A caveat is that it is perhaps predictable that two similar PCR tests (albeit with different primers and detection methods) should agree better with each other than with a dissimilar culture-based method. A potential concern in respect of PCR-based methods is that they may detect residual nucleic acids rather than viable pathogens requiring treatment. However, this argument is partly countered in the present study by the observation that comprehensive culture methodology was able to grow around $86 \%$ viable pathogens that were not reported by routine culture. It is crucial to remember, in context, that all patients in this study were severely-ill, clinically diagnosed with respiratory infection and received contingent antibiotic treatment; it therefore seems more reasonable to consider an organism found by any one method as potentially significant rather than to dismiss those methods that most often recorded a potential pathogen in favour of one that failed to do so simply because it is the 'traditional method'.

If the molecular results are accepted, it becomes possible to identify groups of patients, e.g. those found only to have $S$. aureus pneumonia or Haemophilus influenzae, in whom there 
is wide scope to de-escalate from typical empirical therapy for HAP/VAP with e.g. piperacillin/tazobactam or a carbapenem. This supports a potential to deliver improved antimicrobial stewardship along with better targeted, personalized, treatment of pneumonia. A countervailing risk is that the additional organisms found by PCR instead may prompt unnecessary prescribing. Both the present systems offer semi-quantitative detection which might, in theory, assist assessment of the need for therapy. In a sub-analysis, excluding organisms detected at low concentration by PCR, we did observe increased concordance with routine microbiology, but at the price of discounting organisms confirmed by routine microbiology. Ultimately the best approach may be to combine rapid microbiology with measurement of patient biomarkers as a guide to the need for therapy.

The types and relative frequencies of organisms identified were similar for routine microbiology and both PCR tests, without any obvious bias for either approach to miss particular organisms. The species distribution resembled that reported in numerous HAP/VAP studies from Europe and North America, with S. aureus, P. aeruginosa and Enterobacterales predominant $^{7,8}$. Comparison of resistance gene detection with resistance phenotypes from routine microbiology is complicated by imperfect genotype / phenotype associations and the fact that phenotypic resistance may arise from unsought mechanisms (e.g., a combination of an ESBL and impermeability may confer carbapenem resistance in Enterobacterales). ${ }^{30}$ Moreover, except for mecA on the FilmArray, PCR detection of a resistance gene in a clinical sample does not indicate which bacterial species is hosting that gene. We therefore conducted independent genotypic investigation of isolates identified as resistant by routine microbiology and for further organisms recovered by comprehensive culture. Overall, despite all these caveats, $66 \%$ of Unyvero gene detections and $51 \%$ of FilmArray detections were concordant against a combination of routine microbiology and comprehensive culture results. Crucially, PCR tests identified several key high-consequence resistance genes that had been missed by routine microbiology but which were confirmed by testing bacteria recovered by comprehensive culture. Although the PCR-methods did not provide a full susceptibility profile, they do deliver a swift and sensitive predictor of critical resistance, potentially useful for early identification of patients who should be isolated or have their therapy escalated.

The run times of the machines are measured in hours rather than the days required for routine microbiology. Total turn-around will also reflect the machine's placement in the clinical pathway; this could not be measured here because the tests were run retrospectively under research conditions. However, we established that the median transport time of samples from the ICU to the laboratory was $6 \mathrm{~h}$, with longer times when laboratories were remote from the 
hospital site. If the advantages of speed are to be realised, the machine must be placed in, or near to, the ICU.

The decision of whether to adopt a rapid diagnostic into routine clinical practice will depend not only on its performance but also on the practicalities. Here, we evaluated diagnostic accuracy as well as potential for implementation, finding the FilmArray to be more sensitive than the Unyvero, also faster, smaller and easier to use. Accordingly, we have taken the FilmArray Pneumonia panel forward into INHALE's involving an RCT where patients either receive treatment guided by results of FilmArray test, performed in the ICU, or 'standard to care', comprising empirical antibiotics, adapted once microbiology results become available. This trial will determine if the potential of PCR in ICU HAP/VAP can be realised without compromising patient safety. ${ }^{31}$

\section{Acknowledgements}

We would like to offer our sincerest gratitude to all ICU and laboratory staff at participating sites who assisted with sample identification and collection. We would also like to thank independent research Programme Steering Committee (PSC) who provided quality assurance and oversight. We also thank Norwich Clinical Trials Unit and the INHALE Patient and Public Involvement (I) group for their support. Membership of the PSC and PPI Group is listed on the study website (www.ucl.ac.uk/inhale-project).

\section{Funding}

This paper presents independent research funded by the National Institute for Health Research (NIHR) under its Programme Grants for Applied Research Programme (Reference Number: RPPG-0514-20018). The views expressed are those of the authors and not necessarily those of the National Health Service, the NIHR, or the Department of Health and Social Care.

\section{Transparency declarations:}

DML: Advisory Boards or ad-hoc consultancy Accelerate, Allecra, Antabio, Centauri, Entasis, GSK, Meiji, Menarini, Mutabilis, Nordic, ParaPharm, Pfizer, QPEX, Roche, Shionogi, Summit, T.A.Z., VenatoRx, Wockhardt, Zambon, Paid lectures - Astellas, bioMérieux, Beckman Coulter, Cardiome, Cepheid, Hikma, Merck/MSD, Menarini, Nordic, Pfizer and Shionogi. Relevant shareholdings or options - Dechra, GSK, Merck, Perkin Elmer, Pfizer, T.A.Z, amounting to $<10 \%$ of portfolio value. He also has nominated holdings in Avacta, Byotrol, Destiny, Diaceutics, Evgen, Faron, Fusion Antibodies, Genedrive, Hardide, Renalytics, Scancell and 
Synairgen (all with research/products pertinent to medical and diagnostic innovation) through Enterprise Investment Schemes but has no authority to trade these shares directly.

VG: Advisory boards or ad-hoc consultancy Gilead, Shionogi, bioMérieux, MSD, Vidya Diagnostics

VE: Speaking honoraria, consultancy fees and in-kind contributions from several diagnostic companies including Curetis $\mathrm{GmbH}$, bioMérieux and Oxford Nanopore.

JOG: JOG: has received speaking honoraria, consultancy fees, in-kind contributions or research funding from Oxford Nanopore, Simcere, Becton-Dickinson and Heraeus Medical.

All other authors: None to declare.

\section{Author Contributions}

VE, VG, DML and JOG conceived the study and obtained funding. JB, JH and AMS contributed to study design. VE and JH obtained study approvals. AC built the study database. AA, RB, $\mathrm{DRO}, \mathrm{HR}, \mathrm{CR}$ and BONI managed the machine-based testing, generating the data for analysis. $\mathrm{HR}, \mathrm{DRO}, \mathrm{AA}$ and RB performed the supplementary laboratory analyses. VE and JOG supervised the laboratory work. CR, HR, AA, DRO and VE performed data checks and queries. $\mathrm{JB}$ and FR wrote the statistical analysis plan and designed the BLC analysis, FR performed the analyses. VE, VG, DML and JOG interpreted the data and conceived the scoring system for machine evaluation. VE wrote the manuscript with assistance from RB and DML. All authors reviewed the manuscript and approved the final version. VE, FR and RB had full access to the data and could check their validity.

\section{Data availability statement}

The dataset for this study is available on request from Norwich Clinical Trials Unit

\section{References}

1. Anand N, Kollef MH. The alphabet soup of pneumonia: CAP, HAP, HCAP, NHAP, and VAP. Semin Respir Crit Care Med 2009; 30(1): 3-9.

2. Torres A, Niederman MS, Chastre J, et al. International ERS/ESICM/ESCMID/ALAT guidelines for the management of hospital-acquired pneumonia and ventilatorassociated pneumonia. Guidelines for the management of hospital-acquired pneumonia (HAP)/ventilator-associated pneumonia (VAP) of the European Respiratory Society (ERS), European Society of Intensive Care Medicine (ESICM), European Society of Clinical Microbiology and Infectious Diseases (ESCMID) and Asociación Latinoamericana del Tórax (ALAT) 2017; 50(3): 1700582.

3. Mizgerd JP. Acute lower respiratory tract infection. N Engl J Med 2008; 358(7): 716-27. 
4. Kalil AC, Metersky ML, Klompas M, et al. Management of Adults With Hospital-acquired and Ventilator-associated Pneumonia: 2016 Clinical Practice Guidelines by the Infectious Diseases Society of America and the American Thoracic Society. Clin Infect Dis 2016; 63(5): e61-e111.

5. Piskin N, Aydemir H, Oztoprak N, et al. Inadequate treatment of ventilator-associated and hospital-acquired pneumonia: risk factors and impact on outcomes. BMC Infect Dis 2012; 12: 268.

6. Iregui M, Ward S, Sherman G, Fraser VJ, Kollef MH. Clinical importance of delays in the initiation of appropriate antibiotic treatment for ventilator-associated pneumonia. Chest 2002; 122(1): 262-8.

7. Enne VI, Personne Y, Grgic L, Gant V, Zumla A. Aetiology of hospital-acquired pneumonia and trends in antimicrobial resistance. Curr Opin Pulm Med 2014; 20(3): 252-8.

8. Masterton RG, Galloway A, French G, et al. Guidelines for the management of hospitalacquired pneumonia in the UK: report of the working party on hospital-acquired pneumonia of the British Society for Antimicrobial Chemotherapy. J Antimicrob Chemother 2008; 62(1): 5-34.

9. Russell CD, Koch O, Laurenson IF, et al. Diagnosis and features of hospital-acquired pneumonia: a retospective cohort study. J Hosp Infect 2016; 92(3): 273-9 .

10. Rotstein, C, Evans, G, Born A; et al. Clinical-practise guidelines for hospital-acquired pneumonia and ventilator-associated pneumonia in adults. Can J Infect Dis Med Microbiol; 2008; 19(1): 19-53.

11. Bello, G, Pennisi MA, Di Muzio, F; et al. Clinical impact of pulmonary sampling site in the diagnosis of ventilator-associated pneumonia: A prospective study using bronchoscopic bronchoalveolar lavage. J Crit Care; 2016; 33:151-57.

12. Kitsios GD, Morowitz MJ, Dickson RP, Huffnagle GB, McVerry BJ, Morris A. Dysbiosis in the intensive care unit: Microbiome science coming to the bedside. J Crit Care 2017; 38: 84-91.

13. Poole S, Clark TW. Rapid syndromic molecular testing in pneumonia: The current landscape and future potential. J Infect 2020; 80(1): 1-7.

14. Dhesi Z, Enne VI, O'Grady J, Gant V, Livermore DM. Rapid and Point-of-Care Testing in Respiratory Tract Infections: An Antibiotic Guardian? ACS Pharmacol Trans/ Sci 2020; 3(3): 401-17.

15. Murphy CN, Fowler R, Balada-Llasat JM, et al. Multicenter Evaluation of the BioFire FilmArray Pneumonia/Pneumonia Plus Panel for Detection and Quantification of Agents of Lower Respiratory Tract Infection. Journal of Clinical Microbiology 2020; 58(7): e00128-20.

16. Gadsby NJ, McHugh MP, Forbes C, et al. Comparison of Unyvero P55 Pneumonia Cartridge, in-house PCR and culture for the identification of respiratory pathogens and antibiotic resistance in bronchoalveolar lavage fluids in the critical care setting. Eur $\mathrm{J}$ Clin Microbiol Infect Dis 2019; 38(6): 1171-8.

17. High, J, Enne, VI, Barber, JA; et al. INHALE - The Impact of using FilmArray Pneumonia Panel Molecular Diagnostics for Hospital-Acquired and Ventilator-Associated Pneumonia on Antimicrobial Stewardship and Patient Outcomes in UK Critical Care: Study Protocol for A Multicentre Randomised Controlled Trial. Trials 2021;22:680

18. Niederman, MS, Alder, J, Bassetti, M; Inhaled amikacin adjunctive to intravenous standard-of-care antibiotics in mechanically ventilated patients with Gram-negative pneumonia (INHALE): a double-blind, randomised, placebo-controlled, phase 3 superiority trial. Lancet Infect Dis 2020; 20(3):330-40 
19. England $\mathrm{PH}$. Investigation of bronchoalveolar lavage, sputum and associated specimens. UK Standards for Microbiology Investigations: Standards Unit, Microbiology Services, PHE; 2019. p. 1-38.

20. Torres A, Fabregas N, Ewig S, et al. Sampling methods for ventilator-associated pneumonia: Validation using different histologic and microbiological references. Crit Care Med 2000; 28(8):2799-804

21. Pan-ngum W, Blacksell SD, Lubell $Y$, et al. Estimating the true accuracy of diagnostic tests for dengue infection using bayesian latent class models. PLoS One 2013; 8(1): e50765.

22. Chikere CMU, Wilson, KJ, Allen AJ, et al. Comparative diagnostic accuracy studies with an imperfect reference standard - a comparison of correction methods. BMC Med Res Methodol 202. 21:67.

23. Lim C, Paris DH, Blacksell SD, et al. How to Determine the Accuracy of an Alternative Diagnostic Test when It Is Actually Better than the Reference Tests: A Re-Evaluation of Diagnostic Tests for Scrub Typhus Using Bayesian LCMs. PLos One 2015; 10(5): e0114930.

24. Pickens C, Wunderink RG, Qi C, et al. A multiplex polymerase chain reaction assay for antibiotic stewardship in suspected pneumonia. Diagnostic Microbiology and Infectious Disease 2020; 98(4): 115179.

25. Webber DM, Wallace MA, Burnham C-AD, Anderson NW. Evaluation of the BioFire FilmArray Pneumonia Panel for Detection of Viral and Bacterial Pathogens in Lower Respiratory Tract Specimens in the Setting of a Tertiary Care Academic Medical Center. Journal of Clinical Microbiology 2020; 58(7): e00343-20.

26. Crémet L, Gaborit B, Bouras M, et al. Evaluation of the FilmArray $\left({ }^{\circledR}\right)$ Pneumonia Plus Panel for Rapid Diagnosis of Hospital-Acquired Pneumonia in Intensive Care Unit Patients. Front Microbiol 2020; 11: 2080.

27. Collins ME, Popowitch EB, Miller MB. Eovaluation of a Novel Multiplex PCR Panel Compared to Quantitative Bacterial Culture for Diagnosis of Lower Respiratory Tract Infections. Journal of Clinical Microbiology 2020; 58(5): e02013-19.

28. Limmathurotsakul D, Jamsen K, Arayawichanont A, et al. Defining the True Sensitivity of Culture for the Diagnosis of Melioidosis Using Bayesian Latent Class Models. PLos One 2010; 5(8):e12485.

29. Chang C, Jang JH, Manatunga A, et al. A Bayesian Latent Class Model to Predict Kidney Obstruction in the Absence of Gold Standard. J Am Stat Assoc 2020; 115(532):1645-63.

30. Doumith M, Ellington MJ, Livermore DM, Woodford N. Molecular mechanisms disrupting porin expression in ertapenem-resistant Klebsiella and Enterobacter spp. clinical isolates from the UK. Journal of Antimicrobial Chemotherapy 2009; 63(4): 659-67.

31. Wootton DG, Aston SJ, Felton TW. The challenge of antimicrobial prescribing for hospital-acquired pneumonia. Journal of Hospital Infection 2020; 104(2): 198-9. 
Table 1. Features and Target Panels of the Curetis Unyvero Pneumonia Panel and the BioFire FilmArray Pneumonia Panel multiplex PCR tests.

\begin{tabular}{|c|c|c|}
\hline Characteristic & $\begin{array}{l}\text { Curetis Unyvero HPN } \\
\text { Hospitalised Pneumonia Panel }\end{array}$ & $\begin{array}{l}\text { BioFire FilmArray Pneumonia } \\
\text { Panel plus }\end{array}$ \\
\hline Technology & $\begin{array}{l}\text { Automated sample } \\
\text { preparation, multiplex PCR } \\
\text { and microarray detection of } \\
\text { targets }\end{array}$ & $\begin{array}{l}\text { Automated sample } \\
\text { preparation and nested PCR }\end{array}$ \\
\hline $\begin{array}{l}\text { Regulatory } \\
\text { status }\end{array}$ & CE-IVD1 & CE-IVD \& FDA Cleared ${ }^{2}$ \\
\hline $\begin{array}{l}\text { Hands-on } \\
\text { preparation } \\
\text { time }\end{array}$ & $\begin{array}{l}2 \text { min, using a standard pipette } \\
\text { to transfer sample to the } \\
\text { sample tube. Bacteria are then } \\
\text { lysed for } 30 \text { min in the } \\
\text { 'Lysator' before transfer to the } \\
\text { cartridge. }\end{array}$ & $\begin{array}{l}2 \text { min, using a proprietary } \\
\text { flock swab to transfer the } \\
\text { sample to a sample tube, } \\
\text { which is loaded into the test } \\
\text { pouch with the aid of a } \\
\text { loading station. }\end{array}$ \\
\hline Run-time & 38 & 1h $15 \min$ \\
\hline $\begin{array}{l}\text { Bacteria } \\
\text { sought }\end{array}$ & $\begin{array}{l}\text { Acinetobacter baumannii } \\
\text { complex } \\
\text { Citrobacter freundii } \\
\text { Enterobacter cloacae complex } \\
\text { Escherichia coli } \\
\text { Haemophilus influenzae } \\
\text { Klebsiella aerogenes } \\
\text { Klebsiella oxytoca } \\
\text { Klebsiella pneumoniae } \\
\text { Klebsiella variicola } \\
\text { Moraxella catarrhalis } \\
\text { Morganella morganii } \\
\text { Proteus spp. } \\
\text { Pseudomonas aeruginosa } \\
\text { Serratia marcescens }\end{array}$ & $\begin{array}{l}\text { Acinetobacter calcoaceticus- } \\
\text { baumannii complex } \\
\text { Enterobacter cloacae } \\
\text { complex } \\
\text { Escherichia coli } \\
\text { Haemophilus influenzae } \\
\text { Klebsiella aerogenes } \\
\text { Klebsiella oxytoca } \\
\text { Klebsiella pneumoniae } \\
\text { Moraxella catarrhalis } \\
\text { Proteus spp. } \\
\text { Pseudomonas aeruginosa } \\
\text { Serratia marcescens } \\
\text { Streptococcus agalactiae } \\
\text { Streptococcus pneumoniae }\end{array}$ \\
\hline
\end{tabular}




\begin{tabular}{|c|c|c|}
\hline & $\begin{array}{l}\text { Stenotrophomonas maltophilia } \\
\text { Streptococcus pneumoniae }\end{array}$ & Streptococcus pyogenes \\
\hline $\begin{array}{l}\text { Atypical } \\
\text { organisms } \\
\text { and Fungi } \\
\text { sought }\end{array}$ & $\begin{array}{l}\text { Chlamydophila pneumoniae } \\
\text { Legionella pneumophila } \\
\text { Mycoplasma pneumoniae } \\
\text { Pneumocystis jirovecii }\end{array}$ & $\begin{array}{l}\text { Chlamydophila pneumoniae } \\
\text { Legionella pneumophila } \\
\text { Mycoplasma pneumoniae }\end{array}$ \\
\hline $\begin{array}{l}\text { Viruses } \\
\text { sought }\end{array}$ & None & $\begin{array}{l}\text { Adenovirus } \\
\text { Coronaviruses OD43, NL63, } \\
\text { HKU1 and 229E } \\
\text { Human metapneumovirus } \\
\text { Human rhinovirus/enterovirus } \\
\text { Influenza A } \\
\text { Influenza B } \\
\text { Parainfluenza virus } \\
\text { Respiratory syncytial virus } \\
\text { MERS Coronavirus }\end{array}$ \\
\hline $\begin{array}{l}\text { Antimicrobial } \\
\text { Resistance } \\
\text { Genes } \\
\text { sought }\end{array}$ & 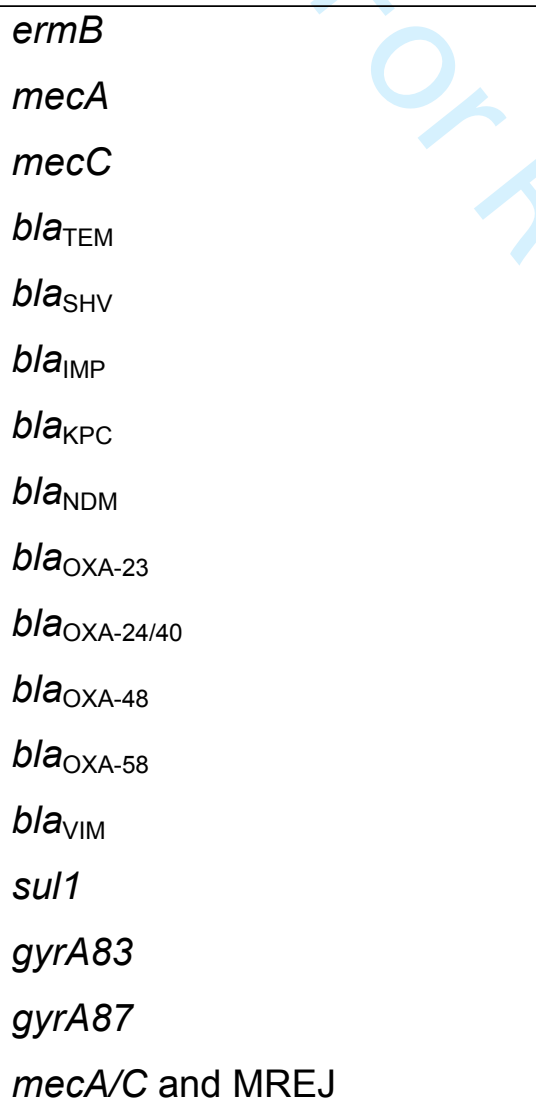 & $\begin{array}{l}\text { bla } a_{\mathrm{KPC}} \\
\text { bla }_{\mathrm{NDM}} \\
\text { bla }_{\mathrm{OXA}-48 \text { like }} \\
\text { bla } \\
\text { bla } \\
\text { bla }_{\mathrm{IMP}} \\
\text { CTX-M }\end{array}$ \\
\hline
\end{tabular}


${ }^{1} \mathrm{~A}$ similar panel, featuring a reduced number of antimicrobial resistance genes, has FDA clearance.

2 We evaluated the Research Use Only (RUO) version 
Table 2. Concordance-based performance of PCR tests compared with routine microbiology

\begin{tabular}{|c|c|c|c|c|c|}
\hline \multirow[t]{2}{*}{ Category } & \multirow[t]{2}{*}{ Definition } & \multicolumn{2}{|c|}{ All Detections } & \multicolumn{2}{|c|}{$\begin{array}{l}\text { Detections reported at } \\
\text { higher concentrations }^{a}\end{array}$} \\
\hline & & $\begin{array}{c}\text { Unyvero } \\
(\%, 95 \% \mathrm{Cl})\end{array}$ & $\begin{array}{l}\text { FilmArray } \\
(\%, 95 \% \mathrm{Cl})\end{array}$ & $\begin{array}{c}\text { Unyvero } \\
(\%, 95 \% \mathrm{Cl})\end{array}$ & $\begin{array}{l}\text { FilmArray } \\
(\%, 95 \% \mathrm{Cl})\end{array}$ \\
\hline $\begin{array}{l}\text { Full positive } \\
\text { concordance }\end{array}$ & $\begin{array}{l}\text { Organisms detected were an } \\
\text { exact match }\end{array}$ & $\begin{array}{c}19.3 \\
(16.2-22.4)\end{array}$ & $\begin{array}{c}18.2 \\
(15.2-21.3)\end{array}$ & $\begin{array}{c}22.4 \\
(19.1-25.8)\end{array}$ & $\begin{array}{c}21.1 \\
(17.9-24.3)\end{array}$ \\
\hline $\begin{array}{l}\text { Full negative } \\
\text { concordance }\end{array}$ & $\begin{array}{l}\text { No organisms detected by either } \\
\text { method }\end{array}$ & $\begin{array}{c}37.3 \\
(33.4-41.1)\end{array}$ & $\begin{array}{c}32.1 \\
(28.4-35.8)\end{array}$ & $\begin{array}{c}42.1 \\
(38.1-46.0)\end{array}$ & $\begin{array}{c}44.5 \\
(40.6-48.4)\end{array}$ \\
\hline Partial concordance & $\begin{array}{l}\text { PCR detected the same organism } \\
\text { as RM plus additional organism(s) }\end{array}$ & $\begin{array}{c}18.2 \\
(15.1-21.2)\end{array}$ & $\begin{array}{c}21.0 \\
(17.8-24.2)\end{array}$ & $\begin{array}{c}11.6 \\
(9.0-14.1)\end{array}$ & $\begin{array}{c}11.8 \\
(9.2-14.3)\end{array}$ \\
\hline Minor discordance & $\begin{array}{l}\text { RM was negative but machine } \\
\text { found } \geq 1 \text { organism }\end{array}$ & $\begin{array}{c}20.6 \\
(17.4-23.8)\end{array}$ & $\begin{array}{c}26.9 \\
(23.4-30.4)\end{array}$ & $\begin{array}{c}15.8 \\
(12.9-18.7)\end{array}$ & $\begin{array}{c}14.5 \\
(11.7-17.3)\end{array}$ \\
\hline Major discordance & $\begin{array}{l}\text { RM found } \geq 1 \text { organism, at least } \\
\text { one of which was on the PCR } \\
\text { panel, but not detected }\end{array}$ & $\begin{array}{c}4.6 \\
(2.9-6.3)\end{array}$ & $\begin{array}{c}1.8 \\
(0.7-2.8)\end{array}$ & $\begin{array}{c}8.1 \\
(5.9-10.3)\end{array}$ & $\begin{array}{c}8.1 \\
(5.9-10.2)\end{array}$ \\
\hline
\end{tabular}

${ }^{a}$ Calculated based on semi-quantitative detections Reported as ++ or +++ by Unyvero or $10^{6}$ or $\geq 10^{7}$ copies $/ \mathrm{ml}$ by FilmArray 
Table 3. Pathogen-specific performance of PCR tests as compared with routine microbiology as the gold standard. $95 \%$ confidence intervals are omitted to aid readability but are included in supplementary Table S7, along with frequencies of detection.

\begin{tabular}{|c|c|c|c|c|c|c|c|c|}
\hline \multirow[t]{2}{*}{ Organism } & \multicolumn{4}{|c|}{ Unyvero } & \multicolumn{4}{|c|}{ FilmArray } \\
\hline & Sensitivity & Specificity & PPV & NPV & Sensitivity & Specificity & PPV & NPV \\
\hline $\begin{array}{l}\text { A. baumannii } \\
\text { complex }\end{array}$ & 100.0 & 99.0 & 45.5 & 100.0 & 100.0 & 99.5 & 66.7 & 100.0 \\
\hline C. freundii & 100.0 & 98.7 & 11.1 & 100.0 & $N A^{* *}$ & NA & NA & NA \\
\hline E. cloacae & 100.0 & 97.5 & 44.4 & 100.0 & 91.7 & 93.4 & 21.6 & 99.8 \\
\hline E. coli & 87.8 & 89.4 & 37.5 & 99.0 & 97.6 & 87.5 & 36.3 & 99.8 \\
\hline H. influenzae & 100.0 & 93.7 & 36.2 & 100.0 & 95.2 & 88.1 & 22.0 & 99.8 \\
\hline K. aerogenes & 50.0 & 99.5 & 50.0 & 99.5 & 100.0 & 99.2 & 54.5 & 100.0 \\
\hline K. oxytoca & 90.9 & 95.0 & 25.0 & 99.8 & 100.0 & 95.2 & 27.5 & 100.0 \\
\hline K. pneumoniae & 83.3 & 94.2 & 37.0 & 99.3 & 92.0 & 91.4 & 31.1 & 99.6 \\
\hline M. catarrhalis & 100.0 & 98.2 & 26.7 & 100.0 & 100.0 & 96.9 & 17.4 & 100.0 \\
\hline M. morganii & 100.0 & 98.3 & 9.1 & 100.0 & NA & NA & NA & NA \\
\hline$P$. aeruginosa & 95.3 & 93.9 & 64.9 & 99.4 & 98.5 & 93.1 & 63.1 & 99.8 \\
\hline S. aureus & 87.2 & 93.2 & 65.4 & 98.0 & 96.2 & 88.9 & 56.2 & 98.2 \\
\hline S. agalactiae & NA & NA & NA & NA & ND & 96.5 & 0.0 & 100.0 \\
\hline S. maltophilia & 92.9 & 94.4 & 28.3 & 99.8 & NA & NA & NA & NA \\
\hline S. marcescens & 77.8 & 98.3 & 41.2 & 99.7 & 100.0 & 98.2 & 45.0 & 100.0 \\
\hline S. pneumoniae & 100.0 & 97.3 & 27.3 & 100.0 & 100.0 & 94.5 & 15.0 & 100.0 \\
\hline S. pyogenes & NA & NA & NA & NA & 100.0 & 98.9 & 22.0 & 100.0 \\
\hline
\end{tabular}

${ }^{*} \mathrm{ND}$ - not determined because routine microbiology detected no positives; ${ }^{* *} \mathrm{NA}$ - not applicable; organism not on test panel 
Table 4. Pathogen-specific performance of routine microbiology and PCR tests estimated using BLC models. 95\% credible intervals are omitted to aid readability but are shown in supplementary table S8. Only organisms on both PCR panels are included

\begin{tabular}{|c|c|c|c|c|c|c|c|c|c|c|c|c|}
\hline \multirow[t]{2}{*}{ Organism } & \multicolumn{4}{|c|}{ Routine microbiology } & \multicolumn{4}{|c|}{ Unyvero } & \multicolumn{4}{|c|}{ FilmArray } \\
\hline & Sensitivity & Specificity & PPV & NPV & Sensitivity & Specificity & PPV & NPV & Sensitivity & Specificity & PPV & NPV \\
\hline $\begin{array}{l}\text { A. baumannii } \\
\text { complex }\end{array}$ & 57.5 & 99.9 & 87.4 & 99.4 & 92.6 & 99.5 & 70.9 & 99.0 & 89.4 & 99.9 & 91.3 & 99.8 \\
\hline E. cloacae & 42.9 & 99.9 & 94.6 & 97.2 & 94.9 & 99.9 & 97.2 & 99.8 & 94.2 & 96.4 & 56.1 & 99.7 \\
\hline E. coli & 38.8 & 99.7 & 96.1 & 88.5 & 89.6 & 99.7 & 98.6 & 97.8 & 98.9 & 98.7 & 94.2 & 99.8 \\
\hline H. influenzae & 36.3 & 99.9 & 96.8 & 93.5 & 96.9 & 99.7 & 97.1 & 99.7 & 95.3 & 93.8 & 62.4 & 99.5 \\
\hline K. aerogenes & 68.7 & 99.9 & 88.9 & 99.6 & 48.4 & 99.6 & 62.1 & 99.3 & 89.8 & 99.4 & 67.8 & 99.9 \\
\hline K. oxytoca & 30.2 & 99.9 & 94.3 & 95.5 & 92.7 & 99.2 & 88.7 & 99.5 & 95.2 & 99.7 & 95.9 & 99.7 \\
\hline K. pneumoniae & 37.8 & 99.5 & 89.3 & 93.5 & 88.9 & 99.8 & 97.6 & 98.8 & 98.1 & 97.7 & 82.2 & 99.8 \\
\hline M. catarrhalis & 27.6 & 99.9 & 86.7 & 98.0 & 89.0 & 99.9 & 95.5 & 99.7 & 95.7 & 98.9 & 71.4 & 99.9 \\
\hline$P$. aeruginosa & 64.7 & 99.7 & 97.3 & 93.9 & 95.8 & 99.9 & 99.2 & 99.2 & 99.2 & 99.3 & 96.6 & 99.9 \\
\hline S. aureus & 65.2 & 99.2 & 95.2 & 92.5 & 91.1 & 99.8 & 99.3 & 98.0 & 99.3 & 95.6 & 83.9 & 99.8 \\
\hline S. marcescens & 48.4 & 99.9 & 92.9 & 98.4 & 83.9 & 99.9 & 95.7 & 99.5 & 96.1 & 99.8 & 94.2 & 99.9 \\
\hline S. pneumoniae & 27.1 & 99.9 & 90.0 & 97.0 & 90.8 & 99.9 & 96.7 & 99.6 & 97.1 & 97.1 & 57.9 & 99.9 \\
\hline
\end{tabular}


Table 5. Concordance of antimicrobial resistance gene detection by PCR and comparator methodology

\begin{tabular}{|l|l|l|l|l|}
\hline $\begin{array}{l}\text { Resistance } \\
\text { Gene }\end{array}$ & \multicolumn{2}{|c|}{ Unyvero } & \multicolumn{2}{c|}{ FilmArray } \\
\hline & $\begin{array}{l}\text { Concordant } \\
\text { detectionsa/total } \\
\text { detections by } \\
\text { PCR }\end{array}$ & $\begin{array}{l}\text { Found in } \\
\text { cultured isolates } \\
\text { but missed in } \\
\text { PCR testing }\end{array}$ & $\begin{array}{l}\text { Concordant } \\
\text { detectionsa/total } \\
\text { detections by } \\
\text { PCR }\end{array}$ & $\begin{array}{l}\text { Found in } \\
\text { cultured } \\
\text { isolates but } \\
\text { missed in } \\
\text { PCR testing }\end{array}$ \\
\hline bla CTX-M $_{\text {Carbapenemase }}$ & $12 / 14$ & 3 & $17 / 32$ & 0 \\
\hline $\begin{array}{l}\text { mecA/mecC } \\
(+M R E J \text { in }\end{array}$ & $13 / 25^{b}$ & 1 & $2 / 3$ & 1 \\
FilmArray) & & 0 & $15 / 32$ & 0 \\
\hline
\end{tabular}

aTotal concordance, based on results from both routine microbiology and comprehensive culture. Each sample is only counted once in the event of both tests being positive

bOnly includes detections where $S$. aureus as well as $m e c A / C$ was also reported by the Unyvero. For total detections see table $S 13$ 
Table 6. Scores allocated to PCR tests based on scoring system designed to evaluate overall performance, ease of use and implementability. See table $\mathrm{S} 1$ for full details of the scoring system.

\begin{tabular}{|c|c|c|c|c|}
\hline \multirow{3}{*}{ Criterion } & \multicolumn{4}{|c|}{$\begin{array}{l}\text { Machine Score } \\
\end{array}$} \\
\hline & \multicolumn{2}{|c|}{$\begin{array}{l}\text { Curetis Unyvero } \\
\text { Pneumonia Panel }\end{array}$} & \multicolumn{2}{|c|}{$\begin{array}{l}\text { BioFire FilmArray } \\
\text { Pneumonia Panel }\end{array}$} \\
\hline & Value & Score & Value & Score \\
\hline $\begin{array}{l}\text { Overall } \\
\text { concordance } \\
\text { (max } 45 \\
\text { points) } \\
\end{array}$ & $74.8 \%$ & 20 & $71.3 \%$ & 16 \\
\hline $\begin{array}{l}\text { Sensitivity } \\
\text { for detection } \\
\text { of common } \\
\text { pathogens } \\
\text { (max } 20 \\
\text { points) }\end{array}$ & $\begin{array}{l}3 \text { targets with } \\
\text { better } \\
\text { performance }\end{array}$ & 6 & $\begin{array}{l}7 \text { targets } \\
\text { with better } \\
\text { performance }\end{array}$ & 14 \\
\hline $\begin{array}{l}\text { Breadth of } \\
\text { panel (max } \\
15 \text { points) }\end{array}$ & $\begin{array}{l}244 \text { unique } \\
\text { detections }\end{array}$ & 15 & $\begin{array}{l}191 \text { unique } \\
\text { detections }\end{array}$ & 12 \\
\hline $\begin{array}{l}\text { Time to } \\
\text { result (max } \\
15 \text { points) }\end{array}$ & $270 \min$ & 7 & $75 \min$ & 14 \\
\hline $\begin{array}{l}\text { Cost per test } \\
\text { (max } 15 \\
\text { points) }{ }^{a}\end{array}$ & +++ & 10 & ++ & 15 \\
\hline $\begin{array}{l}\text { Failure rate } \\
\text { (max } 15 \\
\text { points) }\end{array}$ & $9.1 \%^{\mathrm{b}}$ & 0 & $1.9 \%$ & 11 \\
\hline $\begin{array}{l}\text { Footprint } \\
\text { (max } 5 \\
\text { points) }\end{array}$ & 7.4 sq. $\mathrm{ft}$ & 1 & 3.2 sq. $\mathrm{ft}$ & 5 \\
\hline $\begin{array}{l}\text { Customer } \\
\text { service (max } \\
5 \text { points) }\end{array}$ & - & 3 & 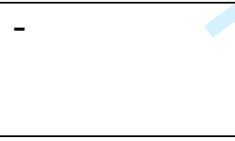 & 4 \\
\hline $\begin{array}{l}\text { Consumable } \\
\text { logistics } \\
\text { (max } 5 \\
\text { points) }\end{array}$ & - & 0 & - & 5 \\
\hline $\begin{array}{l}\text { Ease of use } \\
\text { (max } 10 \\
\text { points) }\end{array}$ & - & 6 & - & 9 \\
\hline $\begin{array}{l}\text { Total (Max } \\
\text { 150) }\end{array}$ & - & 68 & - & 105 \\
\hline
\end{tabular}

a Costs in the range of $£ 150-300 /$ test depending on local purchase conditions. Includes estimates of cost of instrument purchase and operator time.

$\mathrm{b}$ includes both total and partial failures

'Comprised of one point each for space required for storage, storage temperature, delivery cost, delivery timescales and shelf-life 


\section{Figure Legends}

Figure 1. Schematic representation of sample eligibility

Figure 2. Number of significant organisms detected per respiratory sample by routine microbiology or PCR.

Figure 3a. Numbers and types of bacteria detected by routine microbiology culture from respiratory samples included in the study.

Figure 3b. Numbers and type of bacteria detected by PCR from respiratory samples included in the study. Unyvero, solid bars, $n=606$; FilmArray, hatched bars, $n=620$. Species sought by one test only are marked with an asterisk. 
Figure 1. Schematic representation of sample eligibility $210 \times 297 \mathrm{~mm}(600 \times 600 \mathrm{DPI})$ 
Thorax

Page 30 of 52

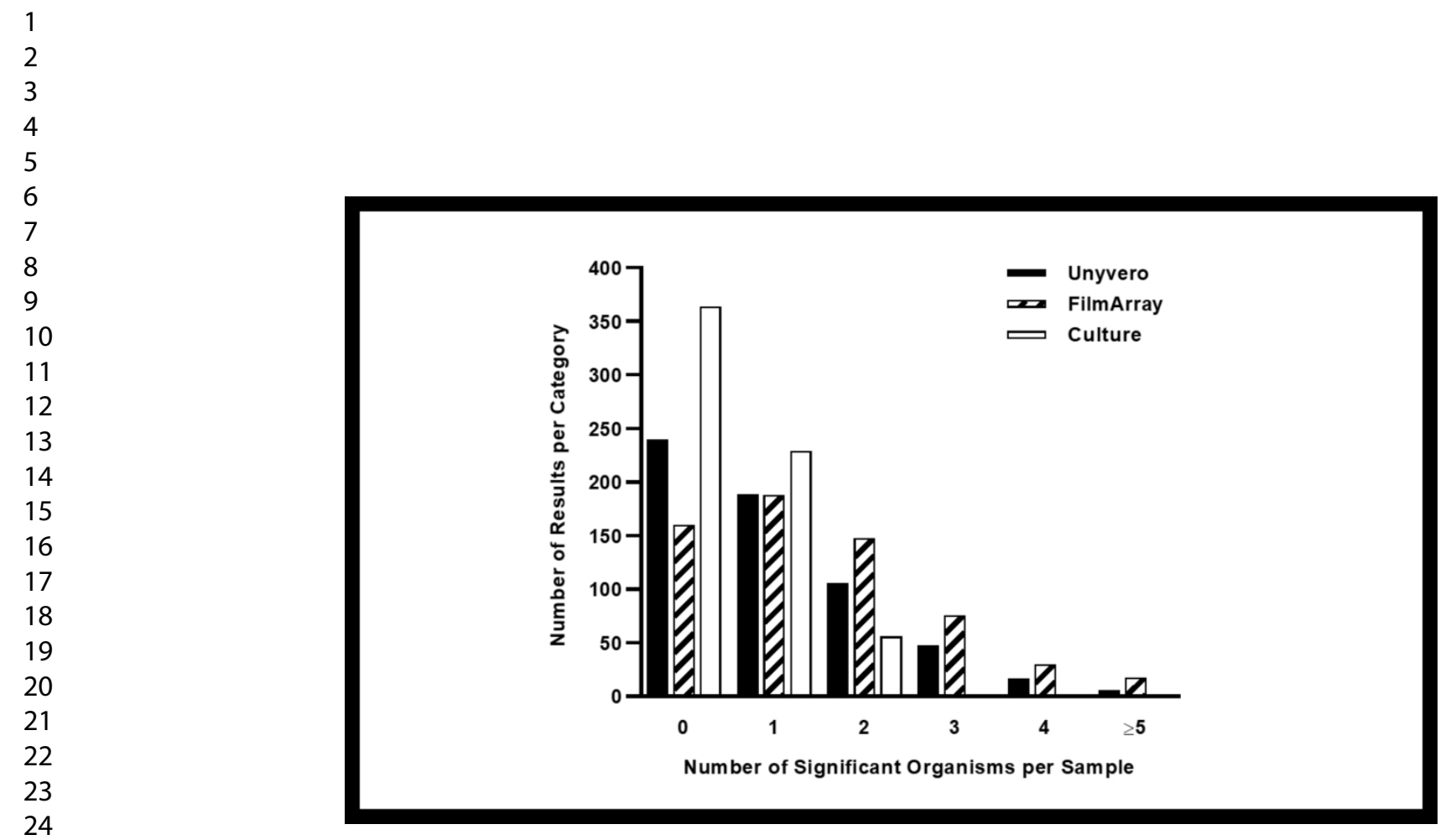

Figure 2. Number of significant organisms detected per respiratory sample by routine microbiology or PCR.

$$
258 \times 148 \mathrm{~mm}(600 \times 600 \text { DPI })
$$

https://mc.manuscriptcentral.com/thorax 

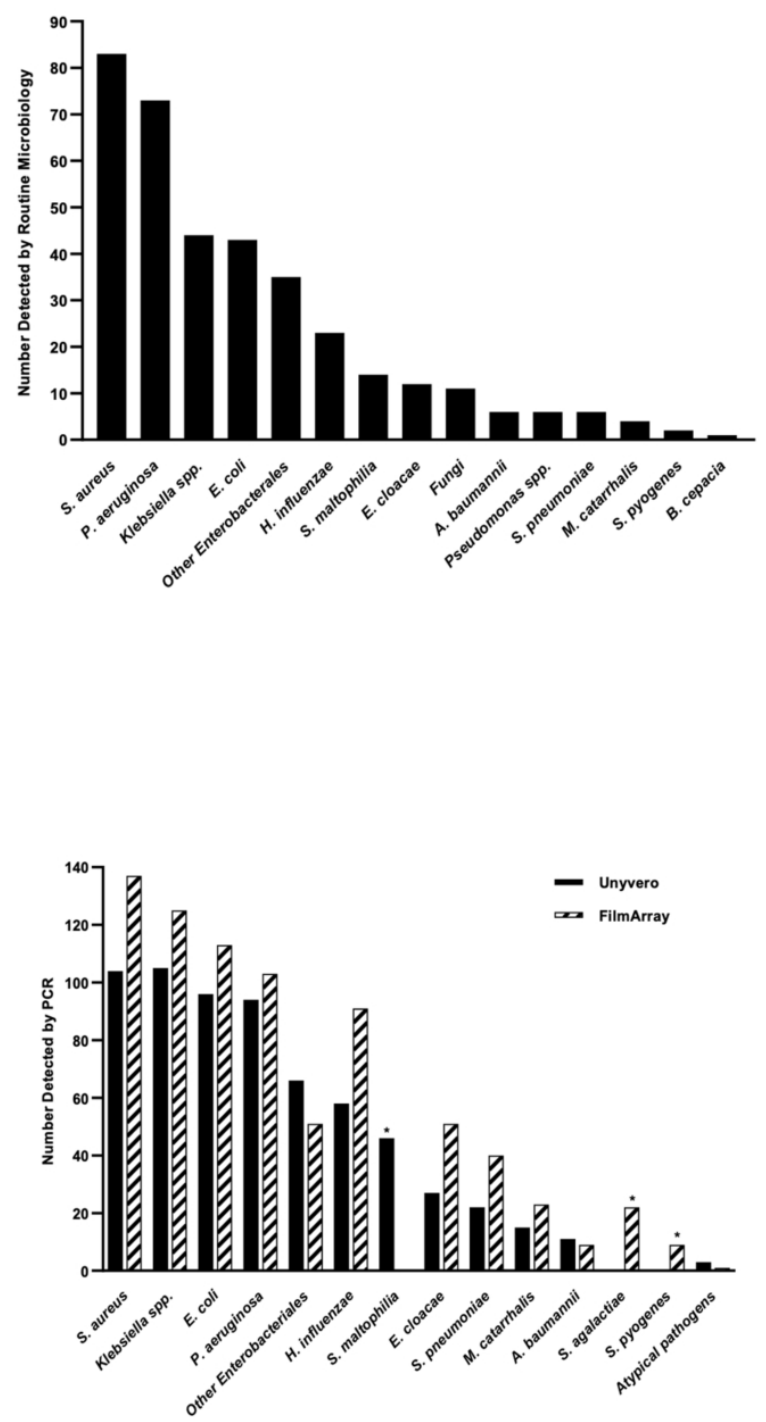

Figure 3. 3a (top) Numbers and types of bacteria detected by routine microbiology culture from respiratory samples included in the study. 3b (bottom) Numbers and type of bacteria detected by PCR from respiratory samples included in the study. Unyvero, solid bars, $n=606$; FilmArray, hatched bars, $n=620$. Species sought by one test only are marked with an asterisk.

$$
210 \times 297 \mathrm{~mm}(600 \times 600 \mathrm{DPI})
$$




\section{Supplementary Appendix for:}

\section{Multicentre evaluation of two multiplex PCR platforms for the rapid microbiological investigation of nosocomial pneumonia in UK ICUs: the INHALE WP1 study}

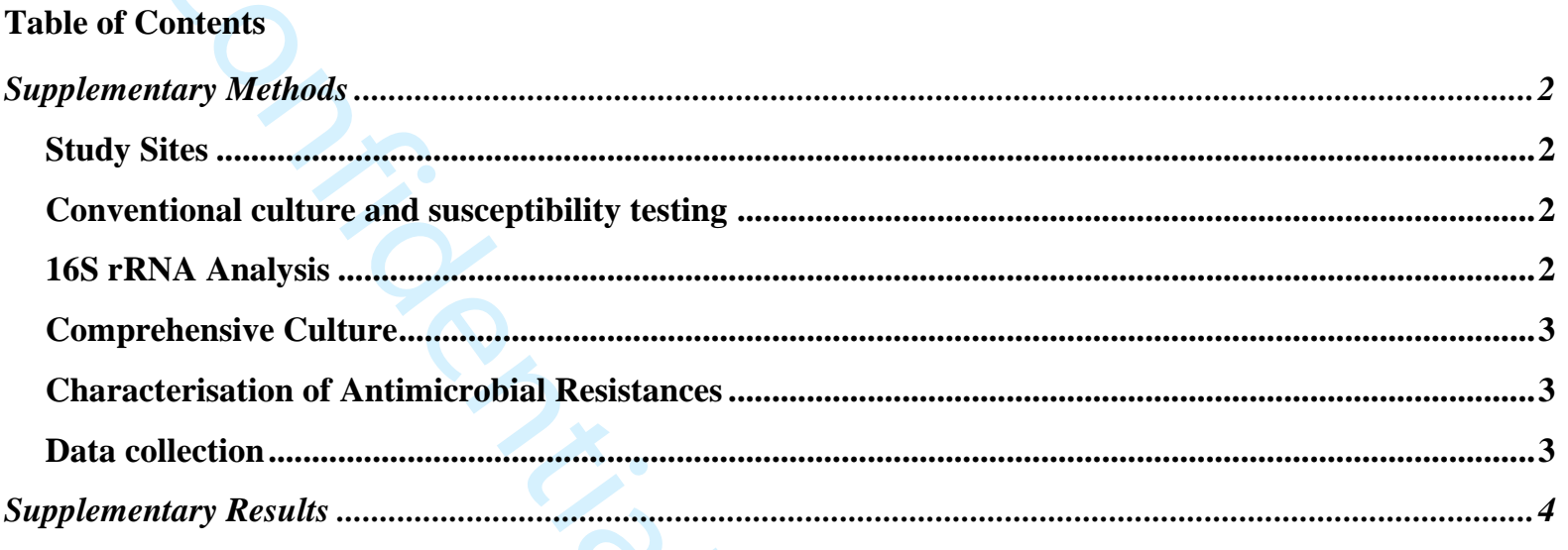

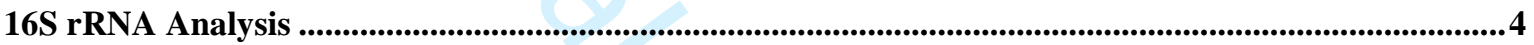

Table S1. Criteria for HAP/VAP diagnostic test progression to RCT phase of the inhale study (WP3) .5

Table S2. Number of bacterial target organisms detected by routine microbiology or PCR in specimens from patients with HAP or VAP.

Table S3. Viral detections made by FilmArray ( $n=620$ eligible samples) and sensitivity and specificity compared with routine virology $(n=102$ samples with routine virology performed with eligible FilmArray result). $95 \%$ confidence intervals are given in brackets.

Table S4. Discordant samples, where one or both PCR tests did not detect potential pathogens which they sought and which were reported by routine microbiology.

Table S5. Summary of frequency of potential pathogens reported by routine microbiology that are absent from the panels of one or both of the PCR tests.

Table S6. Mean numbers of pathogens per eligible and valid sample detected by PCR tests in relation to sample type

Table S7. Pathogen-specific performance of PCR tests when compared with routine microbiology as the gold standard, including $95 \%$ confidence intervals.

Table S8. Pathogen specific performance of routine microbiology and PCR tests using independent BLC modelling, including $95 \%$ confidence intervals.

Table S9. Pathogen-specific performance of routine microbiology, PCR tests and 16S rRNA analysis using independent BLC modelling, showing $95 \%$ confidence intervals.

Table S10. Pathogen-specific performance of PCR tests compared with routine microbiology according to whether the sample was taken before or after antibiotic administration.

Table S11. Pathogen-specific performance of PCR tests compared with routine microbiology in relation to whether samples were fresh or had been frozen prior to PCR testing .

Table S12. Antimicrobial resistance $(\%)$ to selected agents as determined by routine microbiology .... 19

Table S13. Frequency of resistance gene detections by PCR tests among eligible samples $(n=606$ for Unyvero, $n=620$ for FilmArray) 


\section{Conventional culture and susceptibility testing}

Each respiratory specimen was initially cultured locally, at the laboratory serving the participating hospital, according to their standard operating procedures (SOPs). These SOPs were all based on the Public Health England (PHE) UK Standard. ${ }^{1}$ Prior to culture, specimens underwent quality control checks. Salivary specimens or those with excess epithelial cells were rejected. Except in the case of bronchoalveolar lavage (BAL) specimens, the PHE standard specifies initial homogenisation of the respiratory sample with $0.1 \%$ dithiothreitol, followed by a $10^{-5}$ dilution, and inoculation of the diluted and undiluted specimen onto chocolate agar with bacitracin (incorporated, or as a disc), cysteine lactose electrolyte deficient agar (CLED) or MacConkey agar, along with Sabouraud agar for fungi. Blood agar was added at some sites. In the case of BAL specimens, culture is performed on serial dilutions of a sample that has been concentrated by centrifugation.

Plates are incubated at $35-37^{\circ} \mathrm{C}$ in the presence of $5 \% \mathrm{CO}_{2}$ (blood and chocolate agar) or in air (MacConkey and CLED agar) for 40-48h, with daily reading of results. Bacterial pathogens are identified to species level by MALDI-TOF or biochemical methods, followed by antimicrobial susceptibility testing using EUCAST or BSAC interpretive standards.

The PHE standards provide guidance on the interpretation of culture results for BAL samples, whereas interpretation and reporting are left to the discretion of individual laboratories for other sample types.

\section{S rRNA Analysis}

All specimens with a sufficient surplus $(300 \mu \mathrm{l})$ after PCR testing underwent 16S rRNA analysis. Samples were inactivated by incubating for 30 minutes at $99^{\circ} \mathrm{C}$, then DNA was extracted using the ZR Viral RNA/DNA kit and ZR BashingBead Lysis Tubes (Zymo Research). Briefly, $300 \mu$ l of sample were transferred into a bead tube, homogenized in a bead-beater for 30 seconds at 3,500 oscillations per minute, centrifuged for 1 minute at $21,000 \mathrm{~g}$. Next, $200 \mu \mathrm{l}$ of the supernatant were transferred to a clean microcentrifuge tube and DNA was extracted following manufacturer's instructions. Illumina 16S rRNA sequencing was then performed according to the manufacturer's protocol (Illumina, 15044223B). The V3-V4 16S rRNA region was amplified on a LightCycler 480 II instrument (Roche) and sequenced on an Illumina MiSeq system. The Illumina BaseSpace 
16S rRNA pipeline was used to analyse the results. Only samples with at least 10,000 total reads were deemed eligible for analysis. For a genus to be considered significant, it had to comprise at least $1 \%$ of all reads.

\section{Comprehensive Culture}

A sub-set of 103 specimens, selected at random or based on disagreement between culture and PCR for resistance detection, underwent additional culture-based analysis, termed 'comprehensive culture' at the UCL research laboratory, using methodology described previously. ${ }^{2}$ Briefly, a sweep of growth was taken across the plate of a fresh primary culture of the specimen on chocolate agar, and stored in Microbank ${ }^{\mathrm{TM}}$ vials at $-80^{\circ} \mathrm{C}$ until analysis. Ten microliters of neat sample and a $10^{-5}$ dilution in $0.9 \%$ saline were then plated onto chocolate agar, Columbia blood agar (CBA), Brilliance UTI agar (Oxoid, Basingstoke, UK) and Columbia colistinnalidixic acid agar (C-CNA) (Oxoid). The CBA, UTI and C-CNA plates were incubated at $37^{\circ} \mathrm{C}$ in air for $18 \mathrm{~h}$; chocolate agar plates were incubated in $5 \% \mathrm{CO}_{2}$ at $37^{\circ} \mathrm{C}$ for $18 \mathrm{~h}$. Representative bacterial colonies of different morphologies on each medium were identified by MALDI-TOF MS (Bruker GmbH, Mannheim, Germany), either directly from colonies or by using formic acid extraction where necessary

\section{Characterisation of Antimicrobial Resistances}

Additional investigation of antimicrobial resistances, or the genes responsible, was performed on isolates found resistant in microbiology laboratories or by comprehensive culture, or when either of the two molecular systems detected key resistance genes.

Gram-negative bacteria (i) reported resistant to cephalosporins or carbapenems in routine microbiology, or (ii) found to have ESBL or carbapenemase genes using the PCR systems, or (iii) grown in comprehensive culture were tested for resistance to ceftazidime, cefotaxime, ceftriaxone, ertapenem, meropenem and imipenem (Enterobacterales) or imipenem, meropenem, ceftazidime and piperacillin/tazobactam (Acinetobacter spp. and $P$. aeruginosa) by EUCAST disc diffusion methodology. ${ }^{3}$ Potential methicillin-resistant Staphylococcus aureus (MRSA) were screened for resistance to cefoxitin.

When isolates had phenotypes consistent with the presence of antimicrobial resistance genes, genetic testing was performed. Enterobacterales resistant to a carbapenem or to oxyimino cephalosporins, P. aeruginosa resistant to both carbapenems and cephalosporins and A. baumannii resistant to imipenem or meropenem were tested with the Check-MDR CTX103XL kit (Checkpoints, Wageningen, the Netherlands) according to manufacturer's instructions, following extraction of total genomic DNA using the Qiagen DNA Mini Kit (Qiagen). S. aureus isolates resistant to cefoxitin underwent in-house PCR (primers and conditions described previously $)^{4,5}$ for detection of $m e c A$ and $m e c C$ using HotStartTaq PCR Mastermix (Qiagen) on DNA extracted with the Qiagen DNA Mini Kit.

\section{Data collection}

Routine microbiology data available on the Laboratory Information Management Systems (LIMS) of each participating hospital were collected and managed using REDCap ${ }^{6}$ electronic data capture tools hosted at Norwich Clinical Trials Unit. For each included sample, we collected: (i) the culture result as reported to treating clinicians and (ii) details of significant organisms reported, and their full antimicrobial susceptibility 
profile. Any results for relevant respiratory pathogens detected by non-culture-based methods were also included. Hospitals' routine virology data (by other PCR methods) were collected if testing had been performed on the same calendar day as collection of the lower respiratory tract sample for INHALE. We also collected details required to confirm patient eligibility and the times samples were collected, processed and results released. All PCR and supplementary data generated by study staff were also recorded in RedCap. All data were anonymised.

\section{Supplementary Results}

\section{$16 S$ rRNA Analysis}

16S rRNA analysis was originally included to act as an independent molecular reference method. Four-way BLC analysis including 16S rRNA results is shown in Table S5. However, he 16S technique was only able to distinguish organisms to genus level, so PCR and routine microbiology data are likewise grouped to genus level. Streptococci are omitted because of the high density of commensal streptococci found in the respiratory tract and the inability of the $16 \mathrm{~S}$ method to distinguish these from each other and from pathogenic streptococci, including $S$. pneumoniae ${ }^{7}$. For this analysis only, Klebsiella aerogenes was grouped within the genus Enterobacter owing to its relatively recent re-classification. The results show that 16S rRNA analysis was less sensitive than PCR and so was not fit-for-purpose as an alternative molecular reference method; nonetheless, it had had greater sensitivity than routine microbiology. Further optimisation might yield better results. 
Table S1. Criteria for HAP/VAP diagnostic test progression to RCT phase of the inhale study (WP3)

\begin{tabular}{|c|c|c|c|}
\hline Criterion & Description & Point Scoring & $\begin{array}{l}\text { Maximum } \\
\text { available points }\end{array}$ \\
\hline $\begin{array}{l}\text { Concordance - essential } \\
\text { criterion }\end{array}$ & $\begin{array}{l}\text { Major discordance i.e. failures by the test to find pathogen(s) detected } \\
\text { by routine microbiology must account for }<5 \% \text { of all tests performed. }\end{array}$ & NA & NA \\
\hline Overall Concordance & $\begin{array}{l}\text { A measure of the overall accuracy of the test compared to the gold } \\
\text { standard. }\end{array}$ & $\begin{array}{l}1 \text { point is awarded for every } \% \text { point over } 55 \% \text { overall } \\
\text { concordance }\end{array}$ & 45 points \\
\hline Sensitivity & $\begin{array}{l}\text { Sensitivity for detection of common pathogens (i.e. P. aeruginosa, } S \text {. } \\
\text { aureus, } K \text {. pneumoniae, } K \text {. oxytoca, E. coli, E. cloacae, E. aerogenes, } \\
\text { A. baumannii, H. influenzae and } S . \text { pneumoniae) }\end{array}$ & $\begin{array}{l}2 \text { points for every 'win', i.e. the best sensitivity against a } \\
\text { particular pathogen }\end{array}$ & 20 points \\
\hline Breadth of panel & $\begin{array}{l}\text { Each PCR test seeks some targets that the other cannot, principally } \\
\text { resistance genes for Curetis and viruses for Biofire. }\end{array}$ & $\begin{array}{l}\text { Maximum points for most detections of unique targets, } \\
\text { other tests awarded points as a proportion of unique } \\
\text { detection }\end{array}$ & 15 points \\
\hline Time to Result & Time to Result & $\begin{array}{l}1 \text { Point allocated for each } 30 \text { min less than } 8 \mathrm{~h} \text {, the common } \\
\text { dosage interval for antibiotics }\end{array}$ & 15 points \\
\hline $\begin{array}{l}\text { Cost of tests and } \\
\text { equipment }\end{array}$ & Cost per test, A composite measure of both test and equipment cost. & $\begin{array}{l}\text { Cheapest test is awarded the maximum points. One point is } \\
\text { deducted from others for every } 10 \% \text { increase in price } \\
\text { compared to the cheapest. }\end{array}$ & 15 points \\
\hline Failure rate & Failure rate of test and/or machine, full or partial. & 1 point deducted for each $0.5 \%$ of failures & 15 points \\
\hline $\begin{array}{l}\text { Footprint and space } \\
\text { occupied }\end{array}$ & Amount of space required to host machine & $\begin{array}{l}\text { Smallest machine awarded maximum points. Cheapest test } \\
\text { is awarded the maximum points. One point is deducted } \\
\text { from others for every } 10 \% \text { increase in price compared to } \\
\text { the cheapest. }\end{array}$ & 5 points \\
\hline Customer service & $\begin{array}{l}\text { The quality and speed of customer service in the event of breakdown, } \\
\text { ordering, installation etc. }\end{array}$ & $\begin{array}{l}\text { Average score based on assessment from individual users } \\
\text { who have dealt with manufacturers during the study. }\end{array}$ & 5 points \\
\hline Consumable logistics & $\begin{array}{l}\text { Space required for storage of consumables, storage temperature, shelf } \\
\text { life, delivery speed, delivery cost. }\end{array}$ & 1 point for best performing machine for each criterion & 5 points \\
\hline Ease of use & User perception and experience & $\begin{array}{l}\text { Average scored based on assessments from individual } \\
\text { users who have operated machines during the study. }\end{array}$ & 10 points \\
\hline Total & & 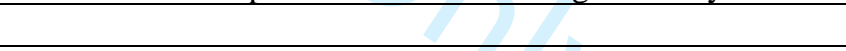 & 150 points \\
\hline
\end{tabular}


Table S2. Number of bacterial target organisms detected by routine microbiology or PCR in specimens from patients with HAP or VAP.

\begin{tabular}{|l|l|l|l|l|l|l|}
\hline \multirow{2}{*}{$\begin{array}{l}\text { Target } \\
\text { Organism }\end{array}$} & \multicolumn{3}{|l|}{ Routine Microbiology } & \multicolumn{2}{l|}{ Unyvero } & \multicolumn{2}{l|}{ FilmArray } \\
\cline { 2 - 7 } & $\begin{array}{l}\text { HAP }(\mathbf{n}= \\
\mathbf{2 6 0})\end{array}$ & $\begin{array}{l}\text { VAP } \\
(\mathbf{n}=\mathbf{3 9 2})\end{array}$ & $\begin{array}{l}\text { HAP }(\mathbf{n}= \\
\mathbf{2 4 0})\end{array}$ & $\begin{array}{l}\text { VAP }(\mathbf{n}= \\
\mathbf{3 6 6})\end{array}$ & $\begin{array}{l}\text { HAP }(\mathbf{n}= \\
\mathbf{2 4 7})\end{array}$ & $\begin{array}{l}\text { VAP }(\mathbf{n}= \\
\mathbf{3 7 3})\end{array}$ \\
\hline A. baumannii & 1 & 5 & 3 & 8 & 2 & 7 \\
\hline C. pneumoniae & 0 & 0 & 0 & 0 & 0 & 0 \\
\hline C. freundii & 0 & 2 & 4 & 5 & NA & NA \\
\hline Coliform & 2 & 4 & NA & NA & NA & NA \\
\hline E. cloacae & 4 & 8 & 9 & 18 & 22 & 29 \\
\hline E. coli & 15 & 28 & 45 & 51 & 51 & 62 \\
\hline H. influenzae & 9 & 14 & 20 & 38 & 34 & 57 \\
\hline K. aerogenes & 0 & 6 & 2 & 4 & 2 & 9 \\
\hline K. pneumoniae & 7 & 19 & 21 & 33 & 31 & 43 \\
\hline K. oxytoca & 3 & 9 & 13 & 27 & 13 & 27 \\
\hline K. variicola & 0 & 0 & 2 & 3 & NA & NA \\
\hline L. pneumophila & 0 & 0 & 1 & 1 & 0 & 0 \\
\hline M. catarrhalis & 1 & 3 & 5 & 10 & 9 & 14 \\
\hline M. morganii & 1 & 0 & 6 & 5 & NA & NA \\
\hline M. pneumoniae & 0 & 0 & 0 & 1 & 0 & 1 \\
\hline Proteus sp. & 2 & 8 & 13 & 16 & 14 & 17 \\
\hline P. aeruginosa & 25 & 48 & 37 & 57 & 41 & 62 \\
\hline Pseudomonas sp. & 0 & 6 & NA & NA & NA & NA \\
\hline S. marcescens & 1 & 9 & 3 & 14 & 3 & 17 \\
\hline S, aureus & 31 & 52 & 46 & 58 & 58 & 79 \\
\hline S. maltophilia & 3 & 11 & 15 & 31 & NA & NA \\
\hline S. agalactiae & 0 & 0 & NA & NA & 10 & 12 \\
\hline S. pneumoniae & 2 & 4 & 9 & 13 & 14 & 26 \\
\hline S. pyogenes & 1 & 1 & NA & NA & 2 & 7 \\
\hline & & & & & \\
\hline
\end{tabular}


Table S3. Viral detections made by FilmArray ( $n=620$ eligible samples) and sensitivity and specificity compared with routine virology $(n=102$ samples with routine virology performed with eligible FilmArray result). $95 \%$ confidence intervals are given in brackets.

\begin{tabular}{|c|c|c|c|c|c|c|}
\hline Virus & $\begin{array}{l}\text { Number of } \\
\text { Detections }\end{array}$ & $\begin{array}{l}\% \\
\text { positive } \\
\text { samples }\end{array}$ & Sensitivity \% & Specificity \% & PPV \% & NPV \% \\
\hline Rhinovirus & 55 & 8.9 & $\begin{array}{l}100.0 \\
(15.8-100.0)\end{array}$ & $\begin{array}{l}85.6 \\
(77.3-91.7)\end{array}$ & $\begin{array}{l}11.8 \\
(1.5-36.4)\end{array}$ & $\begin{array}{l}100.0 \\
(95.9-100.0)\end{array}$ \\
\hline Influenza A & 29 & 4.7 & $\begin{array}{l}100.0 \\
(59.0-100.0)\end{array}$ & $\begin{array}{l}97.0 \\
(91.4-99.4)\end{array}$ & $\begin{array}{l}70.0 \\
(34.8-93.3)\end{array}$ & $\begin{array}{l}100.0 \\
(96.2-100.0)\end{array}$ \\
\hline Influenza B & 25 & 4.0 & $\begin{array}{l}100.0 \\
(39.8-100.0)\end{array}$ & $\begin{array}{l}98.0 \\
(93.1-99.8)\end{array}$ & $\begin{array}{l}66.7 \\
(22.3-95.7)\end{array}$ & $\begin{array}{l}100.0 \\
(96.4-100.0)\end{array}$ \\
\hline Parainfluenza & 17 & 2.7 & $\begin{array}{l}75.0 \\
(19.4-99.4)\end{array}$ & $\begin{array}{l}99.0 \\
(94.7-100.0)\end{array}$ & $\begin{array}{l}75.0 \\
(19.4-99.4)\end{array}$ & $\begin{array}{l}99.0 \\
(94.7-100.0)\end{array}$ \\
\hline $\begin{array}{l}\text { Coronavirus (229E, } \\
\text { HKU1, NL63, OC43) }\end{array}$ & 16 & 2.6 & $\mathrm{ND}^{*}$ & $\begin{array}{l}95.3 \\
(89.3-98.5)\end{array}$ & $\begin{array}{l}0.0 \\
(0.0-52.2)\end{array}$ & $\begin{array}{l}100.0 \\
(96.4-100.0)\end{array}$ \\
\hline Adenovirus & 7 & 1.1 & $\begin{array}{l}50.0 \\
(6.8-93.2)\end{array}$ & $\begin{array}{l}100.0 \\
(96.4-100.0)\end{array}$ & $\begin{array}{l}100.0 \\
(15.8-100.0)\end{array}$ & $\begin{array}{l}98.1 \\
(93.2-99.8)\end{array}$ \\
\hline $\begin{array}{l}\text { Respiratory Syncytial } \\
\text { Virus }\end{array}$ & 6 & 1.0 & $\begin{array}{l}66.7 \\
(9.4-99.2)\end{array}$ & $\begin{array}{l}99.0 \\
(94.7-100.0)\end{array}$ & $\begin{array}{l}66.7 \\
(9.4-99.2)\end{array}$ & $\begin{array}{l}99.0 \\
(94.7-100.0)\end{array}$ \\
\hline $\begin{array}{l}\text { Human } \\
\text { metapneumovirus }\end{array}$ & 5 & 0.8 & $\begin{array}{l}100.0 \\
(2.5-100.0)\end{array}$ & $\begin{array}{l}100.0 \\
(96.5-100.0)\end{array}$ & $\begin{array}{l}100.0 \\
(2.5-100.0)\end{array}$ & $\begin{array}{l}100.0 \\
(96.5--100.0)\end{array}$ \\
\hline MERS coronavirus & 0 & 0 & ND & ND & ND & ND \\
\hline
\end{tabular}

*ND - not determined because routine virology did not report any positives. 
Table S4. Discordant samples, where one or both PCR tests did not detect potential pathogens which they sought and which were reported by routine microbiology.

\begin{tabular}{|c|c|c|c|c|}
\hline $\begin{array}{l}\text { Sample } \\
\text { designation }^{\text {a }}\end{array}$ & Sample type & $\begin{array}{l}\text { Routine microbiology } \\
\text { result }^{\text {b }}\end{array}$ & Unyvero Result $^{\mathbf{c}}$ & FilmArray result $^{\mathrm{c}}$ \\
\hline D001 & SPU & S. aureus & Negative & S. aureus \\
\hline D014 & ETT & M. catarrhalis, S. aureus & $\begin{array}{l}\text { M. catarrhalis, } H . \\
\text { influenzae, } S . \\
\text { pneumoniae }\end{array}$ & $\begin{array}{l}\text { M. catarrhalis, } S . \\
\text { pneumoniae }\end{array}$ \\
\hline D019 & SPU & $\begin{array}{l}P . \text { aeruginosa, } S . \\
\text { marcescens }\end{array}$ & Negative & $\begin{array}{l}P . \text { aeruginosa, } S . \\
\text { marcescens }\end{array}$ \\
\hline D022 & SPU & S. aureus & Negative & S. aureus \\
\hline D037 & ETT & H. influenzae, S. aureus & H. influenzae & $\begin{array}{l}\text { H. influenzae, } S . \\
\text { aureus }\end{array}$ \\
\hline D054 & SPU & S. aureus, H. influenzae & $\begin{array}{l}\text { H. influenzae, } M . \\
\text { catarrhalis, S. aureus }\end{array}$ & $\begin{array}{l}\text { M. catarrhalis, } S \text {. } \\
\text { aureus }\end{array}$ \\
\hline D064 & SPU & $\begin{array}{l}\text { M. catarrhalis, } \boldsymbol{K} . \\
\text { pneumoniae }\end{array}$ & M. catarrhalis & $\begin{array}{l}\text { M. catarrhalis, } S . \\
\text { pyogenes }\end{array}$ \\
\hline D065 & SPU & E. coli, H. influenzae & H. influenzae & E. coli, H. influenzae \\
\hline E005 & SPU & $\begin{array}{l}P . \text { aeruginosa, } \boldsymbol{K} . \\
\text { pneumoniae }\end{array}$ & $\begin{array}{l}P . \text { aeruginosa, } S . \\
\text { maltophila }\end{array}$ & $\begin{array}{l}P . \text { aeruginosa, } S . \\
\text { agalactiae }\end{array}$ \\
\hline F006 & Other & S. aureus & Negative & S. aureus \\
\hline $\mathrm{I} 012$ & SPU & P. aeruginosa, S. aureus & $\begin{array}{l}\text { K. pneumoniae, } P . \\
\text { aeruginosa }\end{array}$ & Invalid result \\
\hline I026 & SPU & P. aeruginosa & Negative & P. aeruginosa \\
\hline $\mathrm{I} 052$ & SPU & $\begin{array}{l}P . \text { aeruginosa, } \boldsymbol{S} . \\
\text { aureus, Coliform }\end{array}$ & P. aeruginosa & $\begin{array}{l}P . \text { aeruginosa, } S . \\
\text { aureus }\end{array}$ \\
\hline I063 & ETT & K. pneumoniae & K. variicola & K. pneumoniae \\
\hline I076 & SPU & E. aerogenes, B. cepacia & Negative & E. aerogenes \\
\hline $\mathrm{J} 002$ & ETT & K. pneumoniae & $\begin{array}{l}E, \text { coli, } K . \text { oxytoca, } S . \\
\text { aureus }\end{array}$ & $\begin{array}{l}\text { E. cloacae, E. coli, } \\
\text { K. pneumoniae, } K . \\
\text { oxytoca, S. aureus }\end{array}$ \\
\hline J007 & SPU & $\begin{array}{l}\text { P. aeruginosa, } S \text {. } \\
\text { maltophila }\end{array}$ & Negative & Negative \\
\hline K060 & ETT & E. aerogenes & Negative & $\begin{array}{l}\text { E. aerogenes, } \\
\text { Proteus sp. }\end{array}$ \\
\hline K101 & BAL & S. aureus & Negative & Negative \\
\hline L002 & ND-BAL & P. mirabilis & Negative & Negative \\
\hline L011 & ND-BAL & E. coli & Negative & E. coli \\
\hline L022 & ND-BAL & E. coli, S. aureus & Negative & E. coli \\
\hline L034 & SPU & E. coli, M. catarrhalis & $\begin{array}{l}\text { K. pneumoniae, } M . \\
\text { catarrhalis }\end{array}$ & $\begin{array}{l}K . \text { pneumoniae, } M . \\
\text { catarrhalis }\end{array}$ \\
\hline L039 & ND-BAL & K. oxytoca & Negative & K. oxytoca \\
\hline M055 & ETT & E. cloacae & E. cloacae & Negative \\
\hline N002 & SPU & E. coli & Negative & $\begin{array}{l}\text { E. coli, S. aureus, } S \text {. } \\
\text { pneumoniae }\end{array}$ \\
\hline N018 & SPU & $\begin{array}{l}\text { E. aerogenes, } H . \\
\text { influenzae }\end{array}$ & H. influenzae & $\begin{array}{l}\text { E. cloacae, } E \text {. } \\
\text { aerogenes, } H . \\
\text { influenzae }\end{array}$ \\
\hline N054 & SPU & E. cloacae, S. aureus & E. cloacae & $\begin{array}{l}\text { E. clocae, } S . \text { aureus, } \\
\text { S. agalactiae }\end{array}$ \\
\hline
\end{tabular}

${ }^{a}$ The prefix letter is an arbitrary code indicating samples were from the same site.

${ }^{\mathrm{b}}$ Discordant pathogen(s) is shown in bold type.

${ }^{c}$ Shading indicates missed detections

BAL, bronchoalveolar lavage; ND-BAL, non-directed bronchoalveolar lavage; ETT, endotracheal tube aspirate; SPU, sputum. 
Table S5. Summary of frequency of potential pathogens reported by routine microbiology that are absent from the panels of one or both of the PCR tests.

\begin{tabular}{|c|c|c|c|}
\hline & Organisma $^{a}$ & $\begin{array}{l}\text { Frequency of } \\
\text { detection by } \\
\text { routine } \\
\text { microbiology }\end{array}$ & Sample type (number) \\
\hline $\begin{array}{l}\text { Organism absent from } \\
\text { Unyvero panel }\end{array}$ & Streptococcus pyogenes & 2 & ETT (1) SPU(1) \\
\hline \multirow{3}{*}{$\begin{array}{l}\text { Organisms absent from } \\
\text { FilmArray panel }\end{array}$} & Citrobacter freundii & 1 & ND-BAL (1) \\
\hline & Morganella morganii & 1 & ETT (1) \\
\hline & $\begin{array}{l}\text { Stenotrophomonas } \\
\text { maltophila }\end{array}$ & 12 & $\begin{array}{l}\text { ETT (6), ND-BAL (1), } \\
\text { SPU(4) Other (1) }\end{array}$ \\
\hline \multirow{9}{*}{$\begin{array}{l}\text { Organisms absent from } \\
\text { both Unyvero and } \\
\text { FilmArray panels }\end{array}$} & Burkholderia cepacia & 1 & SPU (1) \\
\hline & Citrbacter koseri & 5 & $\begin{array}{l}\text { ETT (3), ND-BAL (1), } \\
\text { SPU (1) }\end{array}$ \\
\hline & Raoultella ornitholytica & 2 & ETT (1), SPU (1) \\
\hline & $\begin{array}{l}\text { Achromobacter } \\
\text { xylosoxidans }\end{array}$ & 1 & ETT (1) \\
\hline & $\begin{array}{l}\text { Corynebacterium } \\
\text { striatum }\end{array}$ & 1 & ETT (1) \\
\hline & Enterococcus faecium & 1 & ETT (1) \\
\hline & Group G streptococcus & 1 & ETT (1) \\
\hline & Pseudomonas putida & 1 & ETT (1) \\
\hline & S. pseudopneumoniae & 1 & ETT (1) \\
\hline
\end{tabular}

${ }^{\mathrm{a}}$ In addition, there were 3 cases ( 1 x ETT and $2 \times$ SPU) where routine microbiology reported 'coliforms' not identified to species level, 1 (Other specimen type) where it reported Pseudomonas spp. and 2 (both SPU) where it reported Streptococcus spp. Without a species level identification is impossible to distinguish whether these represent cases where the PCR tests failed to detect organisms that they sought, or cases where the particular species was not sought by these tests.

Table S6. Mean numbers of pathogens per eligible and valid sample detected by PCR tests in relation to sample type

\begin{tabular}{|l|l|l|l|}
\hline \multirow{2}{*}{ PCR Test } & \multicolumn{3}{|c|}{ Sample Type } \\
\cline { 2 - 4 } & BAL or ND-BAL & ETT & Sputum \\
\hline Unyvero & $0.81 \pm 0.96(\mathrm{n}=63)$ & $1.08 \pm 1.18(\mathrm{n}=278)$ & $1.13 \pm 1.19(\mathrm{n}=251)$ \\
\hline FilmArray & $1.23 \pm 1.37(\mathrm{n}=64)$ & $1.44 \pm 1.26(\mathrm{n}=285)$ & $1.63 \pm 1.40(\mathrm{n}=257)$ \\
\hline
\end{tabular}

BAL, bronchoalveolar lavage; ND-BAL, non-directed bronchoalveolar lavage; ETT, endotracheal tube aspirate 
Table S7. Pathogen-specific performance of PCR tests when compared with routine microbiology as the gold standard, including 95\% confidence intervals

\begin{tabular}{|c|c|c|c|c|c|c|c|c|c|c|c|c|c|}
\hline \multicolumn{14}{|c|}{ UNYVERO } \\
\hline \multirow{3}{*}{$\begin{array}{c}\text { Target Organism } \\
P . \text { aeruginosa }\end{array}$} & \multirow{3}{*}{$\begin{array}{c}\text { Number of Detections } \\
94\end{array}$} & \multicolumn{3}{|c|}{ Sensitivity } & \multicolumn{3}{|c|}{ Specificity } & \multicolumn{3}{|c|}{ PPV } & \multicolumn{3}{|c|}{ NPV } \\
\hline & & \multirow{2}{*}{$\begin{array}{c}\% \\
95.3\end{array}$} & \multicolumn{2}{|c|}{$95 \% \mathrm{CI}$} & \multirow{2}{*}{$\begin{array}{c}\% \\
93.9\end{array}$} & \multicolumn{2}{|c|}{$95 \% \mathrm{CI}$} & \multirow{2}{*}{$\begin{array}{c}\% \\
64.9\end{array}$} & \multicolumn{2}{|c|}{$95 \% \mathrm{CI}$} & \multirow{2}{*}{$\begin{array}{c}\% \\
99.4\end{array}$} & \multicolumn{2}{|c|}{$95 \% \mathrm{CI}$} \\
\hline & & & 86.9 & 99.0 & & 91.6 & 95.8 & & 54.4 & 74.5 & & 98.3 & 99.9 \\
\hline S. aureus & 104 & 87.2 & 77.7 & 93.7 & 93.2 & 90.7 & 95.2 & 65.4 & 55.4 & 74.4 & 98.0 & 96.4 & 99.0 \\
\hline K. pneumoniae & 54 & 83.3 & 62.6 & 95.3 & 94.2 & 91.9 & 95.9 & 37.0 & 24.3 & 51.3 & 99.3 & 98.2 & 99.8 \\
\hline K. oxytoca & 40 & 90.9 & 58.7 & 99.8 & 95.0 & 92.9 & 96.6 & 25.0 & 12.7 & 41.2 & 99.8 & 99.0 & 100.0 \\
\hline E. coli & 96 & 87.8 & 73.8 & 95.9 & 89.4 & 86.5 & 91.8 & 37.5 & 27.8 & 48.0 & 99.0 & 97.7 & 99.7 \\
\hline E. cloacae & 27 & 100.0 & 73.5 & 100.0 & 97.5 & 95.9 & 98.6 & 44.4 & 25.5 & 64.7 & 100.0 & 99.4 & 100.0 \\
\hline K. aerogenes & 6 & 50.0 & 11.8 & 88.2 & 99.5 & 98.5 & 99.9 & 50.0 & 11.8 & 88.2 & 99.5 & 98.5 & 99.9 \\
\hline A. baumannii & 11 & 100.0 & 47.8 & 100.0 & 99.0 & 97.8 & 99.6 & 45.5 & 16.7 & 76.6 & 100.0 & 99.4 & 100.0 \\
\hline H. influenzae & 58 & 100.0 & 83.9 & 100.0 & 93.7 & 91.4 & 95.5 & 36.2 & 24.0 & 49.9 & 100.0 & 99.3 & 100.0 \\
\hline S. pneumoniae & 22 & 100.0 & 54.1 & 100.0 & 97.3 & 95.7 & 98.5 & 27.3 & 10.7 & 50.2 & 100.0 & 99.4 & 100.0 \\
\hline M. catarrhalis & 15 & 100.0 & 39.8 & 100.0 & 98.2 & 96.8 & 99.1 & 26.7 & 7.8 & 55.1 & 100.0 & 99.4 & 100.0 \\
\hline S. marcescens & 17 & 77.8 & 40.0 & 97.2 & 98.3 & 96.9 & 99.2 & 41.2 & 18.4 & 67.1 & 99.7 & 98.8 & 100.0 \\
\hline C. pneumoniae & 0 & & & & & & & & & & & & \\
\hline L. pneumophila & 2 & & & & & & & & & & & & \\
\hline M. pneumoniae & 1 & & & & & & & & & & & & \\
\hline C. freundii & 9 & 100.0 & 2.5 & 100.0 & 98.7 & 97.4 & 99.4 & 11.1 & 0.3 & 48.2 & 100.0 & 99.4 & 100.0 \\
\hline M. morganii & 11 & 100.0 & 2.5 & 100.0 & 98.3 & 97.0 & 99.2 & 9.1 & 0.2 & 41.3 & 100.0 & 99.4 & 100.0 \\
\hline S. maltophilia & 46 & 92.9 & 66.1 & 99.8 & 94.4 & 92.3 & 96.1 & 28.3 & 16.0 & 43.5 & 99.8 & 99.0 & 100.0 \\
\hline
\end{tabular}




\begin{tabular}{|c|c|c|c|c|c|c|c|c|c|c|c|c|c|}
\hline \multicolumn{14}{|c|}{ FILMARRAY } \\
\hline \multirow{3}{*}{$\begin{array}{l}\text { Target Organism } \\
\text { P. aeruginosa }\end{array}$} & \multirow{3}{*}{$\begin{array}{c}\text { Number of Detections } \\
103\end{array}$} & \multicolumn{3}{|c|}{ Sensitivity } & \multicolumn{3}{|c|}{ Specificity } & \multicolumn{3}{|c|}{ PPV } & \multicolumn{3}{|c|}{ NPV } \\
\hline & & \multirow{2}{*}{$\begin{array}{r}\% \\
98.5\end{array}$} & \multicolumn{2}{|c|}{$95 \% \mathrm{CI}$} & \multirow{2}{*}{$\begin{array}{r}\% \\
93.1\end{array}$} & \multicolumn{2}{|c|}{$95 \% \mathrm{CI}$} & \multirow{2}{*}{$\begin{array}{r}\% \\
63.1\end{array}$} & \multicolumn{2}{|c|}{$95 \% \mathrm{CI}$} & \multirow{2}{*}{$\begin{array}{r}\% \\
99.8\end{array}$} & \multicolumn{2}{|c|}{$95 \% \mathrm{CI}$} \\
\hline & & & 91.8 & 100.0 & & 90.7 & 95.1 & & 53.0 & 72.4 & & 98.9 & 100.0 \\
\hline S. aureus & 137 & 96.2 & 89.4 & 99.2 & 88.9 & 85.9 & 91.4 & 56.2 & 47.5 & 64.7 & 99.4 & 98.2 & 99.9 \\
\hline K. pneumoniae & 74 & 92.0 & 74.0 & 99.0 & 91.4 & 88.9 & 93.6 & 31.1 & 20.8 & 42.9 & 99.6 & 98.7 & 100.0 \\
\hline K. oxytoca & 40 & 100.0 & 71.5 & 100.0 & 95.2 & 93.2 & 96.8 & 27.5 & 14.6 & 43.9 & 100.0 & 99.4 & 100.0 \\
\hline E. coli & 113 & 97.6 & 87.4 & 99.9 & 87.5 & 84.6 & 90.1 & 36.3 & 27.4 & 45.9 & 99.8 & 98.9 & 100.0 \\
\hline E. cloacae & 51 & 91.7 & 61.5 & 99.8 & 93.4 & 91.1 & 95.3 & 21.6 & 11.3 & 35.3 & 99.8 & 99.0 & 100.0 \\
\hline K. aerogenes & 11 & 100.0 & 54.1 & 100.0 & 99.2 & 98.1 & 99.7 & 54.5 & 23.4 & 83.3 & 100.0 & 99.4 & 100.0 \\
\hline A. baumannii & 9 & 100.0 & 54.1 & 100.0 & 99.5 & 98.6 & 99.9 & 66.7 & 29.9 & 92.5 & 100.0 & 99.4 & 100.0 \\
\hline H. influenzae & 91 & 95.2 & 76.2 & 99.9 & 88.1 & 85.3 & 90.6 & 22.0 & 14.0 & 31.9 & 99.8 & 99.0 & 100.0 \\
\hline S. pneumoniae & 40 & 100.0 & 54.1 & 100.0 & 94.5 & 92.3 & 96.1 & 15.0 & 5.7 & 29.8 & 100.0 & 99.4 & 100.0 \\
\hline M. catarrhalis & 23 & 100.0 & 39.8 & 100.0 & 96.9 & 95.2 & 98.1 & 17.4 & 5.0 & 38.8 & 100.0 & 99.4 & 100.0 \\
\hline S. marcescens & 20 & 100.0 & 66.4 & 100.0 & 98.2 & 96.8 & 99.1 & 45.0 & 23.1 & 68.5 & 100.0 & 99.4 & 100.0 \\
\hline C. pneumoniae & 0 & & & & & & & & & & & & \\
\hline L. pneumophila & 0 & & & & & & & & & & & & \\
\hline M. pneumoniae & 1 & & & & & & & & & & & & \\
\hline S. agalactiae & 22 & NA & 0.0 & 100.0 & 96.5 & 94.7 & 97.8 & 0.0 & 0.0 & 15.4 & 100.0 & 99.4 & 100.0 \\
\hline S. pyogenes & 9 & 100.0 & 15.8 & 100.0 & 98.9 & 97.7 & 99.5 & 22.2 & 2.8 & 60.0 & 100.0 & 99.4 & 100.0 \\
\hline
\end{tabular}


Table S8. Pathogen specific performance of routine microbiology and PCR tests using independent BLC modelling, including 95\% confidence intervals

\begin{tabular}{|c|c|c|c|c|c|c|c|c|c|c|c|c|}
\hline \multicolumn{13}{|c|}{ ROUTINE MICROBIOLOGY } \\
\hline \multirow{3}{*}{$\begin{array}{l}\text { Target Organism } \\
\text { P. aeruginosa }\end{array}$} & \multicolumn{3}{|c|}{ Sensitivity } & \multicolumn{3}{|c|}{ Specificity } & \multicolumn{3}{|c|}{ PPV } & \multicolumn{3}{|c|}{ NPV } \\
\hline & \multirow{2}{*}{$\begin{array}{r}\% \\
64.7\end{array}$} & \multicolumn{2}{|c|}{$95 \% \mathrm{CI}$} & \multirow{2}{*}{$\begin{array}{r}\% \\
99.7\end{array}$} & \multicolumn{2}{|c|}{$95 \% \mathrm{CI}$} & \multirow{2}{*}{$\begin{array}{r}\% \\
97.3\end{array}$} & \multicolumn{2}{|c|}{$95 \% \mathrm{CI}$} & \multirow{2}{*}{$\begin{array}{r}\text { \% } \\
93.9\end{array}$} & \multicolumn{2}{|c|}{$95 \% \mathrm{CI}$} \\
\hline & & 54.7 & 73.9 & & 98.9 & 100.0 & & 91.5 & 99.6 & & 91.7 & 95.8 \\
\hline S. aureus & 65.2 & 56.1 & 74.1 & 99.2 & 98.2 & 99.8 & 95.2 & 88.8 & 98.6 & 92.5 & 90.0 & 94.7 \\
\hline K. рпеитопіае & 37.8 & 26.0 & 51.4 & 99.5 & 98.6 & 99.9 & 89.3 & 73.2 & 97.7 & 93.5 & 90.9 & 95.6 \\
\hline K. oxytoca & 30.2 & 18.3 & 45.5 & 99.9 & 99.3 & 100.0 & 94.3 & 73.0 & 99.8 & 95.5 & 93.7 & 97.0 \\
\hline E. coli & 38.8 & 29.8 & 48.2 & 99.7 & 98.9 & 100.0 & 96.1 & 86.8 & 99.5 & 88.5 & 85.5 & 91.1 \\
\hline E. cloacae & 42.9 & 25.6 & 61.3 & 99.9 & 99.3 & 100.0 & 94.6 & 71.6 & 99.8 & 97.2 & 95.5 & 98.4 \\
\hline K. aerogenes & 68.7 & 32.1 & 94.7 & 99.9 & 99.4 & 100.0 & 88.9 & 54.4 & 99.6 & 99.6 & 98.5 & 99.9 \\
\hline A. baumannii & 57.5 & 27.1 & 84.9 & 99.9 & 99.4 & 100.0 & 87.4 & 50.8 & 99.5 & 99.4 & 98.5 & 99.8 \\
\hline H. influenzae & 36.3 & 24.8 & 49.1 & 99.9 & 99.3 & 100.0 & 96.8 & 84.5 & 99.9 & 93.5 & 91.0 & 95.4 \\
\hline S. pneитопіае & 27.1 & 15.9 & 46.2 & 99.9 & 99.4 & 100.0 & 90.0 & 61.0 & 99.6 & 97.0 & 95.0 & 98.3 \\
\hline M. catarrhalis & 27.6 & 15.8 & 50.4 & 99.9 & 99.4 & 100.0 & 86.7 & 50.5 & 99.4 & 98.0 & 96.5 & 99.0 \\
\hline S. marcescens & 48.4 & 27.7 & 69.7 & 99.9 & 99.3 & 100.0 & 92.9 & 67.4 & 99.7 & 98.4 & 97.1 & 99.2 \\
\hline
\end{tabular}

\begin{tabular}{|c|c|c|c|c|c|c|c|c|c|c|c|c|}
\hline \multicolumn{13}{|c|}{ UNYVERO } \\
\hline \multirow{3}{*}{$\begin{array}{l}\text { Target Organism } \\
\text { P. aeruginosa }\end{array}$} & \multicolumn{3}{|c|}{ Sensitivity } & \multicolumn{3}{|c|}{ Specificity } & \multicolumn{3}{|c|}{$\begin{array}{l}\text { PPV } \\
\end{array}$} & \multicolumn{3}{|c|}{ NPV } \\
\hline & \multirow{2}{*}{$\begin{array}{r}\% \\
95.8\end{array}$} & \multicolumn{2}{|c|}{$95 \%$ CI } & \multirow{2}{*}{$\begin{array}{r}\% \\
99.9\end{array}$} & \multicolumn{2}{|c|}{$95 \% \mathrm{CI}$} & \multirow{2}{*}{$\begin{array}{r}\% \\
99.2\end{array}$} & \multicolumn{2}{|c|}{ 95\% CI } & \multirow{2}{*}{$\begin{array}{r}\% \\
99.2\end{array}$} & \multicolumn{2}{|c|}{$95 \% \mathrm{CI}$} \\
\hline & & 89.6 & 99.0 & & 99.2 & 100.0 & & 95.8 & 100.0 & & 98.0 & 99.8 \\
\hline S. aureus & 91.1 & 82.9 & 96.1 & 99.8 & 99.2 & 100.0 & 99.3 & 96.4 & 100.0 & 98.0 & 95.9 & 99.2 \\
\hline K. pneuтопiae & 88.9 & 73.3 & 97.5 & 99.8 & 99.0 & 100.0 & 97.6 & 90.6 & 99.9 & 98.8 & 96.6 & 99.8 \\
\hline K. oxytoca & 92.7 & 80.3 & 98.8 & 99.2 & 98.1 & 99.9 & 88.7 & 74.7 & 98.6 & 99.5 & 98.6 & 99.9 \\
\hline
\end{tabular}




\begin{tabular}{|l|l|l|l|l|l|l|l|l|l|l|l|l|}
\hline E. coli & 89.6 & 80.5 & 96.4 & 99.7 & 98.9 & 100.0 & 98.6 & 94.4 & 99.9 & 97.8 & 95.8 & 99.3 \\
\hline E. cloacae & 94.9 & 74.9 & 99.8 & 99.9 & 99.3 & 100.0 & 97.2 & 86.9 & 99.9 & 99.8 & 98.5 & 100.0 \\
\hline K. aerogenes & 48.4 & 21.4 & 80.3 & 99.6 & 98.8 & 99.9 & 62.1 & 25.5 & 93.0 & 99.3 & 98.1 & 99.8 \\
\hline A. baumannii & 92.6 & 66.2 & 99.7 & 99.5 & 98.6 & 99.9 & 70.9 & 39.7 & 94.6 & 99.9 & 99.4 & 100.0 \\
\hline H. influenzae & 96.9 & 84.8 & 99.9 & 99.7 & 98.8 & 100.0 & 97.1 & 89.3 & 99.9 & 99.7 & 98.2 & 100.0 \\
\hline S. pneumoniae & 90.8 & 63.2 & 99.6 & 99.9 & 99.3 & 100.0 & 96.7 & 83.8 & 99.9 & 99.6 & 97.8 & 100.0 \\
\hline M. catarrhalis & 89.0 & 60.6 & 99.5 & 99.9 & 99.4 & 100.0 & 95.5 & 78.1 & 99.8 & 99.7 & 98.5 & 100.0 \\
\hline S. marcescens & 83.9 & 64.1 & 95.6 & 99.9 & 99.4 & 100.0 & 95.7 & 78.0 & 99.8 & 99.5 & 98.7 & 99.9 \\
\hline
\end{tabular}

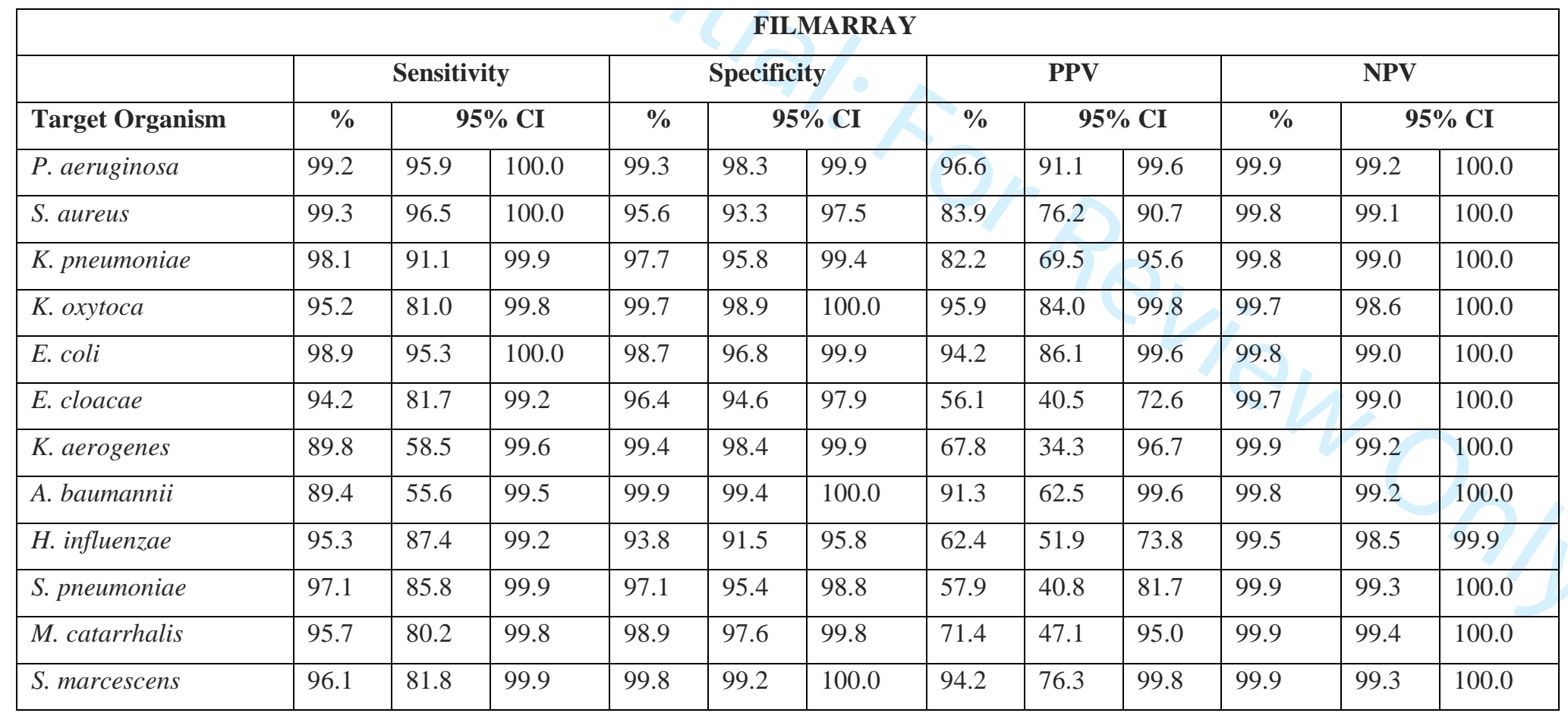


Table S9. Pathogen-specific performance of routine microbiology, PCR tests and 16S rRNA analysis using independent BLC modelling, showing 95\% confidence intervals

\begin{tabular}{|c|c|c|c|c|c|c|c|c|c|c|c|c|}
\hline \multicolumn{13}{|c|}{ ROUTINE MICROBIOLOGY } \\
\hline & \multicolumn{3}{|c|}{ Sensitivity } & \multicolumn{3}{|c|}{ Specificity } & \multicolumn{3}{|c|}{ PPV } & \multicolumn{3}{|c|}{ NPV } \\
\hline Target Genus & $\%$ & $95 \%$ & CI & $\%$ & 95 & $\mathbf{C I}$ & $\%$ & 95 & CI & $\%$ & & \\
\hline Acinetobacter & 54.2 & 26.8 & 82.0 & 99.9 & 99.3 & 100.0 & 87.5 & 49.5 & 99.5 & 99.2 & 98.3 & 99.8 \\
\hline Escherichia & 38.7 & 29.1 & 48.7 & 99.6 & 98.6 & 99.9 & 95.3 & 85.2 & 99.3 & 88.3 & 85.2 & 91.0 \\
\hline Enterobacter & 46.4 & 30.2 & 63.3 & 99.8 & 99.2 & 100.0 & 95.9 & 79.0 & 99.9 & 96.2 & 93.7 & 97.8 \\
\hline Haemophilus & 30.4 & 20.2 & 42.8 & 99.8 & 99.2 & 100.0 & 96.6 & 83.7 & 99.9 & 90.9 & 87.7 & 93.4 \\
\hline Klebsiella & 38.0 & 27.8 & 48.5 & 99.4 & 98.3 & 99.8 & 92.1 & 79.4 & 98.1 & 89.6 & 86.6 & 92.3 \\
\hline Moraxella & 23.9 & 15.4 & 43.4 & 99.9 & 99.3 & 100.0 & 85.7 & 50.4 & 99.5 & 97.5 & 96.0 & 98.6 \\
\hline Pseudomonas & 75.3 & 64.8 & 83.8 & 99.5 & 98.5 & 100.0 & 96.6 & 89.8 & 99.8 & 95.8 & 93.7 & 97.4 \\
\hline Proteus & 33.6 & 18.3 & 52.2 & 99.7 & 98.9 & 100.0 & 84.8 & 57.4 & 97.7 & 96.5 & 94.6 & 97.8 \\
\hline Staphylococcus & 66.3 & 56.4 & 75.2 & 99.6 & 98.6 & 99.9 & 97.5 & 91.6 & 99.7 & 92.5 & 89.6 & 94.8 \\
\hline Serratia & 51.8 & 30.3 & 73.7 & 99.8 & 99.2 & 100.0 & 92.4 & 65.7 & 99.7 & 98.4 & 97.1 & 99.3 \\
\hline
\end{tabular}

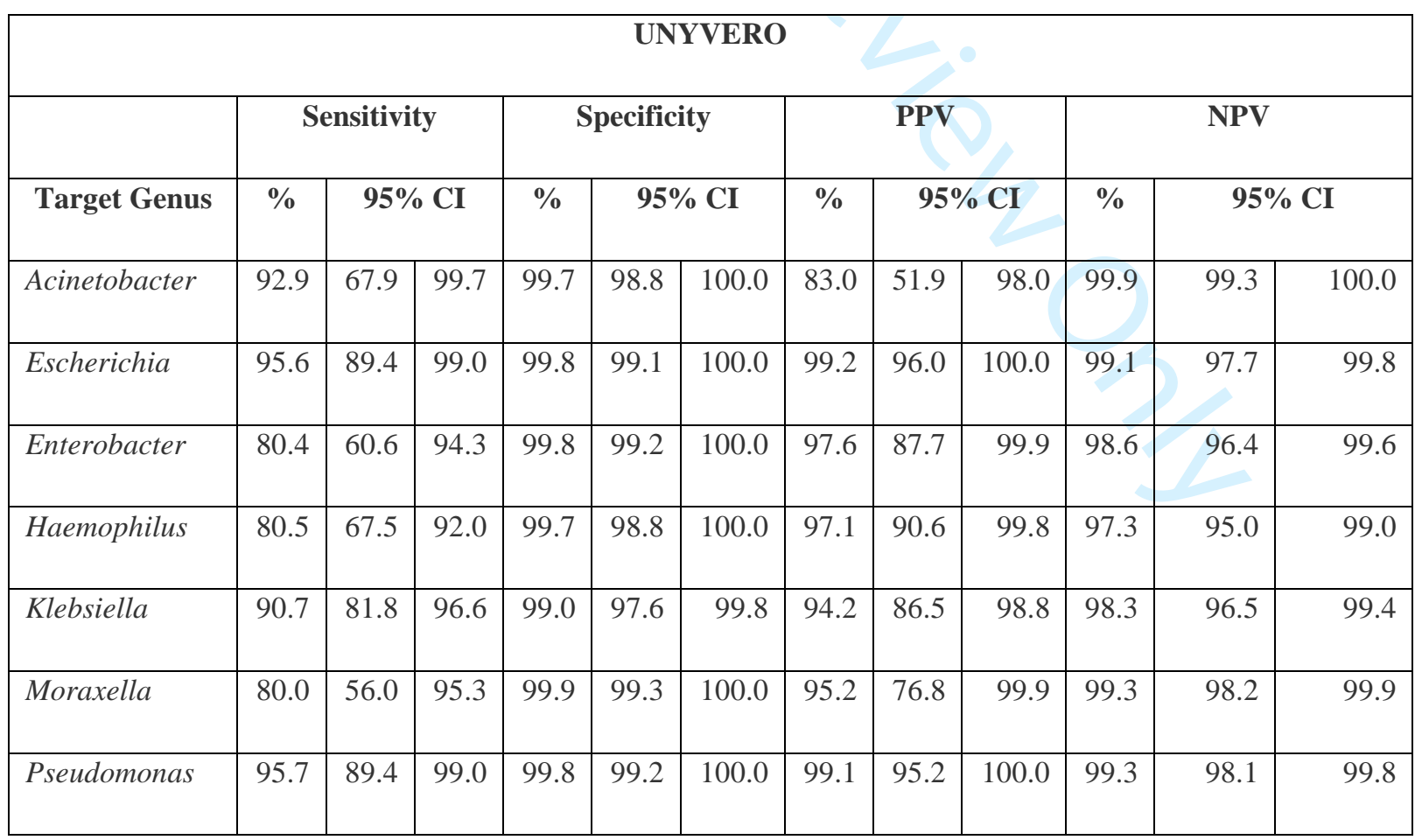




\begin{tabular}{|l|r|r|r|r|r|r|r|r|r|r|r|r|}
\hline Proteus & 96.6 & 83.5 & 99.8 & 99.7 & 99.0 & 100.0 & 94.7 & 82.5 & 99.7 & 99.8 & 99.0 & 100.0 \\
\hline Staphylococcus & 92.6 & 85.2 & 97.1 & 99.8 & 99.1 & 100.0 & 99.2 & 96.1 & 100.0 & 98.2 & 96.3 & 99.3 \\
\hline Serratia & 85.1 & 64.5 & 96.3 & 99.9 & 99.3 & 100.0 & 95.5 & 78.0 & 99.8 & 99.5 & 98.7 & 99.9 \\
\hline
\end{tabular}

\begin{tabular}{|c|c|c|c|c|c|c|c|c|c|c|c|c|}
\hline \multicolumn{13}{|c|}{ FILMARRAY } \\
\hline \multirow{3}{*}{$\begin{array}{l}\text { Target Genus } \\
\text { Acinetobacter }\end{array}$} & \multicolumn{3}{|c|}{ Sensitivity } & \multicolumn{3}{|c|}{ Specificity } & \multicolumn{3}{|c|}{ PPV } & \multicolumn{3}{|c|}{ NPV } \\
\hline & \multirow{2}{*}{$\begin{array}{l}\% \\
83.2\end{array}$} & \multicolumn{2}{|c|}{$95 \% \mathrm{CI}$} & \multirow{2}{*}{$\begin{array}{c}\% \\
99.9\end{array}$} & \multicolumn{2}{|c|}{$95 \% \mathrm{CI}$} & \multirow{2}{*}{$\begin{array}{c}\% \\
91.4\end{array}$} & \multicolumn{2}{|c|}{$95 \% \mathrm{CI}$} & \multirow{2}{*}{$\begin{array}{c}\% \\
99.7\end{array}$} & \multicolumn{2}{|c|}{$95 \% \mathrm{CI}$} \\
\hline & & 53.5 & 98.4 & & 99.2 & 100.0 & & 61.8 & 99.7 & & 99.0 & 100.0 \\
\hline Escherichia & 99.2 & 95.9 & 100.0 & 97.8 & 96.0 & 99.0 & 90.9 & 83.7 & 95.9 & 99.8 & 99.1 & 100.0 \\
\hline Enterobacter & 95.1 & 84.6 & 99.4 & 96.8 & 94.6 & 98.7 & 68.5 & 51.9 & 86.8 & 99.6 & 98.8 & 100.0 \\
\hline Haemophilus & 96.8 & 89.8 & 99.5 & 95.5 & 92.9 & 97.6 & 75.8 & 63.2 & 86.7 & 99.5 & 98.5 & 99.9 \\
\hline Klebsiella & 96.4 & 90.0 & 99.7 & 97.8 & 95.9 & 99.1 & 88.9 & 79.7 & 95.8 & 99.3 & 98.0 & 99.9 \\
\hline Moraxella & 96.1 & 81.2 & 99.9 & 99.1 & 97.9 & 99.8 & 77.7 & 54.3 & 95.8 & 99.9 & 99.3 & 100.0 \\
\hline Pseudomonas & 98.5 & 93.4 & 99.9 & 99.0 & 97.8 & 99.7 & 94.4 & 88.5 & 98.2 & 99.7 & 98.8 & 100.0 \\
\hline Proteus & 96.9 & 84.9 & 99.9 & 99.3 & 98.3 & 99.9 & 88.9 & 74.1 & 97.8 & 99.8 & 99.1 & 100.0 \\
\hline Staphylococcus & 99.3 & 96.4 & 100.0 & 95.6 & 93.2 & 97.5 & 84.5 & 76.4 & 91.0 & 99.8 & 99.1 & 100.0 \\
\hline Serratia & 96.0 & 80.7 & 99.8 & 99.7 & 98.9 & 100.0 & 91.1 & 72.2 & 99.1 & 99.9 & 99.3 & 100.0 \\
\hline
\end{tabular}

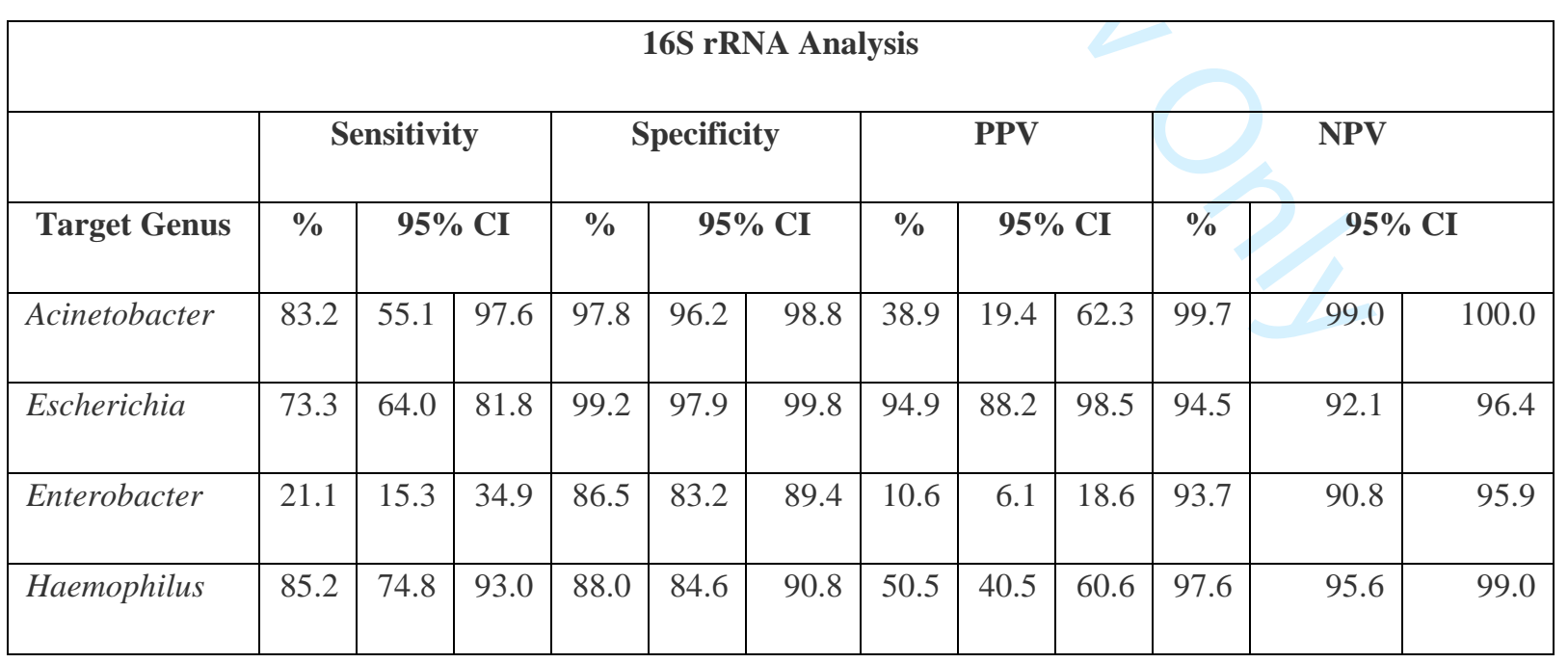




\begin{tabular}{|l|r|r|r|r|r|r|r|r|r|r|r|r|}
\hline Klebsiella & 66.8 & 56.0 & 77.2 & 95.7 & 93.5 & 97.4 & 74.0 & 63.5 & 83.6 & 94.0 & 91.4 & 96.1 \\
\hline Moraxella & 58.0 & 34.5 & 78.4 & 99.9 & 99.2 & 100.0 & 93.1 & 69.7 & 99.7 & 98.6 & 97.3 & 99.4 \\
\hline Pseudomonas & 89.0 & 81.0 & 94.5 & 94.7 & 92.3 & 96.5 & 74.5 & 65.1 & 82.5 & 98.0 & 96.4 & 99.0 \\
\hline Proteus & 54.6 & 36.1 & 71.7 & 99.9 & 99.2 & 100.0 & 95.5 & 77.4 & 99.8 & 97.6 & 96.0 & 98.7 \\
\hline Staphylococcus & 82.8 & 74.3 & 89.2 & 77.9 & 73.8 & 81.8 & 47.4 & 40.2 & 55.0 & 95.0 & 92.1 & 96.9 \\
\hline Serratia & 90.6 & 72.7 & 98.6 & 87.8 & 84.8 & 90.5 & 19.8 & 12.1 & 29.8 & 99.7 & 98.8 & 100.0 \\
\hline
\end{tabular}


Table S10. Pathogen-specific performance of PCR tests compared with routine microbiology according to whether the sample was taken before or after antibiotic administration.

\begin{tabular}{|c|c|c|c|c|c|c|c|c|}
\hline \multicolumn{9}{|c|}{ UNYVERO } \\
\hline & \multicolumn{4}{|c|}{ Before Antibiotics $(\mathrm{n}=329)$} & \multicolumn{4}{|c|}{ After Antibiotics $(\mathrm{n}=\mathbf{2 7 7})$} \\
\hline \multirow{2}{*}{$\begin{array}{l}\text { Target } \\
\text { organism }\end{array}$} & \multicolumn{2}{|c|}{ Sensitivity } & \multicolumn{2}{|c|}{ Specificity } & \multicolumn{2}{|c|}{ Sensitivity } & \multicolumn{2}{|c|}{ Specificity } \\
\hline & $\%$ & $95 \% \mathrm{CI}$ & $\%$ & $95 \% \mathrm{CI}$ & $\%$ & $95 \% \mathrm{CI}$ & $\%$ & $95 \% \mathrm{CI}$ \\
\hline P. aeruginosa & 100.0 & $89.1-100.0$ & 93.3 & $89.8-95.8$ & 90.6 & $75.0-98.0$ & 94.7 & $91.1-97.1$ \\
\hline S. aureus & 91.5 & $79.6-97.6$ & 93.3 & $89.7-95.9$ & 80.6 & $62.5-92.5$ & 93.1 & $89.2-95.1$ \\
\hline K. pneumoniae & 83.3 & $51.6-97.9$ & 94.6 & $91.6-96.8$ & 83.3 & $51.6-97.9$ & 93.6 & $89.9-96.2$ \\
\hline K. oxytoca & 100.0 & $59.0-100.0$ & 93.5 & $90.2-95.9$ & 75.0 & $19.4-99.4$ & 96.7 & $93.8-98.5$ \\
\hline E. coli & 81.0 & $58.1-94.6$ & 89.9 & $86.0-93.1$ & 95.0 & $75.1-99.9$ & 88.7 & $84.2-92.3$ \\
\hline E. cloacae & 100.0 & $54.1-100.0$ & 97.2 & $94.8-98.7$ & 100.0 & $54.1-100.0$ & 97.8 & $95.2-99.2$ \\
\hline K. aerogenes & 50.0 & $11.8-88.2$ & 99.4 & $97.8-99.9$ & ND & ND & 99.6 & $98.0-100.0$ \\
\hline A. baumannii & 100.0 & $15.8-100.0$ & 98.8 & $96.9-99.7$ & 100.0 & $29.2-100.0$ & 99.3 & $97.4-99.9$ \\
\hline H. influenzae & 100.0 & $71.5-100.0$ & 93.1 & $89.7-95.6$ & 100.0 & $69.2-100.0$ & 94.4 & $90.9-96.8$ \\
\hline S. pneumoniae & 100.0 & $47.8-100.0$ & 97.8 & $95.6-99.1$ & 100.0 & $2.5-100.0$ & 96.7 & $93.9-98.5$ \\
\hline M. catarrhalis & 100.0 & $29.2-100.0$ & 98.8 & $96.9-99.7$ & 100.0 & $2.5-100.0$ & 97.5 & $94.8-99.0$ \\
\hline S. marcescens & 85.7 & $42.1-99.6$ & 98.4 & $96.4-99.5$ & 50.0 & $1.3-98.7$ & 98.2 & $95.8-99.4$ \\
\hline C. freundii & 100.0 & $2.5-100.0$ & 97.9 & $95.7-99.1$ & ND & ND & 99.6 & $98.0-100.0$ \\
\hline M. morganii & 100.0 & $2.5-100.0$ & 98.5 & $96.5-99.5$ & ND & ND & 98.2 & $95.8-99.4$ \\
\hline S. maltophila & 100.0 & $71.5-100.0$ & 93.1 & $89.7-95.6$ & 66.7 & $9.4-99.2$ & 96.0 & $92.9-98.0$ \\
\hline
\end{tabular}

ND - no detections

\begin{tabular}{|c|c|c|c|c|c|c|c|c|}
\hline \multicolumn{9}{|c|}{ FILMARRAY } \\
\hline & \multicolumn{4}{|c|}{ Before Antibiotics $(n=337)$} & \multicolumn{4}{|c|}{ After Antibiotics $(n=283)$} \\
\hline \multirow{2}{*}{$\begin{array}{l}\text { Target } \\
\text { organism }\end{array}$} & \multicolumn{2}{|c|}{ Sensitivity } & \multicolumn{2}{|c|}{ Specificity } & \multicolumn{2}{|c|}{ Sensitivity } & \multicolumn{2}{|c|}{ Specificity } \\
\hline & $\%$ & $95 \% \mathrm{CI}$ & $\%$ & $95 \% \mathrm{CI}$ & $\%$ & $95 \% \mathrm{CI}$ & $\%$ & $95 \% \mathrm{CI}$ \\
\hline P. aeruginosa & 100.0 & $89.1-100.0$ & 92.5 & $88.9-95.2$ & 97.1 & $84.7-99.9$ & 94.0 & $90.3-96.6$ \\
\hline S. aureus & 100.0 & $92.6-100.0$ & 88.6 & $84,3-92.0$ & 90.6 & $75.0-98.0$ & 89.2 & $84.7-92.8$ \\
\hline K. pneumoniae & 84.6 & $54.6-98.1$ & 92.3 & $88.8-94.9$ & 100.0 & $73.5-100.0$ & 90.4 & $86.3-93.6$ \\
\hline K. oxytoca & 100.0 & $59.0-100.0$ & 93.6 & $90.4-96.0$ & 100.0 & $39.8-100.0$ & 97.1 & $94.4-98.8$ \\
\hline E. coli & 95.5 & $77.2-99.9$ & 88.6 & $84.5-91.9$ & 100.0 & $83.2-100.0$ & 86.3 & $81.6-90.2$ \\
\hline E. cloacae & 83.3 & $35.9-99.6$ & 92.7 & $89.4-95.3$ & 100.0 & $54.1-100.0$ & 94.2 & $90.8-96.7$ \\
\hline K. aerogenes & 100.0 & $54.1-100.0$ & 98.8 & $96.9-99.7$ & ND & ND & 99.6 & $98.0-100.0$ \\
\hline A. baumannii & 100.0 & $29.2-100.0$ & 99.4 & $97.9-99.9$ & 100.0 & $29.2-100.0$ & 99.6 & $98.0-100.0$ \\
\hline H. influenzae & 100.0 & $71.5-100.0$ & 88.0 & $84.0-99.4$ & 90.0 & $55.5-99.7$ & 88.3 & $83.9-91.8$ \\
\hline S. pneumoniae & 100.0 & $47.8-100.0$ & 96.4 & $93.8-98.1$ & 100.0 & $2.5-100.0$ & 92.2 & $88.4-95.0$ \\
\hline M. catarrhalis & 100.0 & $29.2-100.0$ & 97.9 & $95.7-99.2$ & 100.0 & $2.5-100.0$ & 95.7 & $92.7-97.8$ \\
\hline S. marcescens & 100.0 & $59.0-100.0$ & 98.5 & $96.5-99.5$ & 100.0 & $15.8-100.0$ & 97.9 & $95.4-99.2$ \\
\hline S. agalactiae & ND & ND & 97.3 & $95.0-98.8$ & ND & ND & 95.4 & $92.3-97.5$ \\
\hline S. pyogenes & ND & ND & 98.2 & $96.2-99.3$ & 100.0 & $15.8-100.0$ & 99.6 & $98.0-100.0$ \\
\hline
\end{tabular}

ND - no detections

All samples had to be taken within $12 \mathrm{~h}$ of antibiotic adminstration 
Table S11. Pathogen-specific performance of PCR tests compared with routine microbiology in relation to whether samples were fresh or had been frozen prior to PCR testing

\begin{tabular}{|c|c|c|c|c|c|c|c|c|}
\hline \multicolumn{9}{|c|}{ UNYVERO } \\
\hline & \multicolumn{4}{|c|}{ Fresh Samples $(n=456)$} & \multicolumn{4}{|c|}{ Frozen Samples $(n=150)$} \\
\hline \multirow{2}{*}{$\begin{array}{l}\text { Target } \\
\text { organism }\end{array}$} & \multicolumn{2}{|c|}{ Sensitivity } & \multicolumn{2}{|c|}{ Specificity } & \multicolumn{2}{|c|}{ Sensitivity } & \multicolumn{2}{|c|}{ Specificity } \\
\hline & $\%$ & $95 \% \mathrm{CI}$ & $\%$ & $95 \% \mathrm{CI}$ & $\%$ & $95 \% \mathrm{CI}$ & $\%$ & $95 \% \mathrm{CI}$ \\
\hline P. aeruginosa & 98.0 & $89.6-100.0$ & 93.8 & $91.0-96.0$ & 84.6 & $54.6-98.1$ & 94.2 & $88.8-97.4$ \\
\hline S. aureus & 84.0 & $70.9-92.8$ & 92.6 & $89.6-95.0$ & 92.9 & $76.5-99.1$ & 95.1 & $89.6-98.2$ \\
\hline K. pneumoniae & 77.8 & $52.4-93.6$ & 94.3 & $91.7-96.3$ & 100.0 & $54.1-100.0$ & 93.8 & $88.5-97.1$ \\
\hline K. oxytoca & 88.9 & $51.8-99.7$ & 94.9 & $92.4-96.7$ & 100.0 & 15.8100 .0 & 95.3 & $90.5-98.1$ \\
\hline E. coli & 87.9 & $71.8-96.6$ & 90.1 & $86.8-92.7$ & 87.5 & $47.3-99.7$ & 87.3 & $80.7-92.3$ \\
\hline E. cloacae & 100.0 & $54.1-100.0$ & 96.9 & $94.8-98.3$ & 100.0 & $54.1-100.0$ & 99.3 & $96.2-100.0$ \\
\hline K. aerogenes & 25.0 & $0.6-80.6$ & 99.3 & $98.1-99.9$ & 100.0 & $15.8-100.0$ & 100.0 & $97.5-100.0$ \\
\hline A. baumannii & 100.0 & $47.8-100.0$ & 98.9 & $97.4-99.6$ & ND & ND & 99.3 & $96.3-100.0$ \\
\hline H. influenzae & 100.0 & $75.3-100.0$ & 95.0 & $92.6-96.9$ & 100.0 & $63.1-100.0$ & 89.4 & $83.2-94.0$ \\
\hline S. pneumoniae & 100.0 & $2.5-100.0$ & 97.4 & $95.4-98.6$ & 100.0 & $47.8-100.0$ & 97.2 & $93.1-99.2$ \\
\hline M. catarrhalis & 100.0 & $39.8-100.0$ & 98.2 & $96.5-99.2$ & ND & ND & 98.0 & $94.3-99.6$ \\
\hline S. marcescens & 83.3 & $35.9-99.6$ & 98.2 & $96.5-99.2$ & 66.7 & $9.4-99.2$ & 98.6 & $95.2-99.8$ \\
\hline C. freundii & 100.0 & $2.5-100.0$ & 98.7 & $97.2-99.5$ & ND & ND & 98.7 & $95.3-99.8$ \\
\hline M. morganii & 100.0 & $2.5-100.0$ & 98.0 & $96.3-99.1$ & ND & ND & 99.3 & $96.3-100.0$ \\
\hline S. maltophila & 100.0 & $69.2-100.0$ & 95.3 & $92.9-97.1$ & 75.0 & $19.4-99.4$ & 91.8 & $86.1-95.7$ \\
\hline
\end{tabular}

\begin{tabular}{|c|c|c|c|c|c|c|c|c|}
\hline \multicolumn{9}{|c|}{ FILMARRAY } \\
\hline & \multicolumn{4}{|c|}{ Fresh Samples $(n=476)$} & \multicolumn{4}{|c|}{ Frozen Samples $(n=144)$} \\
\hline \multirow{2}{*}{$\begin{array}{l}\text { Target } \\
\text { organism }\end{array}$} & \multicolumn{2}{|c|}{ Sensitivity } & \multicolumn{2}{|c|}{ Specificity } & \multicolumn{2}{|c|}{ Sensitivity } & \multicolumn{2}{|c|}{ Specificity } \\
\hline & $\%$ & $95 \% \mathrm{CI}$ & $\%$ & $95 \% \mathrm{CI}$ & $\%$ & $95 \% \mathrm{CI}$ & $\%$ & $95 \% \mathrm{CI}$ \\
\hline P. aeruginosa & 98.1 & $89.9-100.0$ & 92.9 & $90.0-95.2$ & 100.0 & $75.3-100.0$ & 93.9 & $88.3-97.3$ \\
\hline S. aureus & 94.4 & $84.6-98.8$ & 87.4 & $83.9-90.4$ & 100.0 & $86.8-100.0$ & 94.1 & $88.2-97.6$ \\
\hline K. pneumoniae & 89.5 & $66.9-98.7$ & 91.9 & $89.0-84.2$ & 100.0 & $54.1-100.0$ & 89.9 & $83.6-94.3$ \\
\hline K. oxytoca & 100.0 & $66.4-100.0$ & 94.6 & $92.2-96.5$ & 100.0 & $15.8-100.0$ & 97.2 & $92.9-99.2$ \\
\hline E. coli & 97.0 & $94.2-99.9$ & 88.0 & $84.6-90.9$ & 100.0 & $66.4-100.0$ & 85.9 & $78.9-91.3$ \\
\hline E. cloacae & 100.0 & $54.1-100.0$ & 92.6 & $89.8-94.8$ & 83.3 & $35.9-99.6$ & 96.4 & $91.7-98.8$ \\
\hline K. aerogenes & 100.0 & $39.8-100.0$ & 98.9 & $97.5-99.7$ & 100.0 & $15.8-100.0$ & 100.0 & $97.4-100.0$ \\
\hline A. baumannii & 100.0 & $54.1-100.0$ & 99.6 & $98.5-99.9$ & ND & ND & 99.3 & $96.2-100.0$ \\
\hline H. influenzae & 92.9 & $66.1-99.8$ & 89.6 & $86.5-92.2$ & 100.0 & $59.0-100.0$ & 83.2 & $75.9-89.0$ \\
\hline S. pneumoniae & 100.0 & $2.5-100.0$ & 95.2 & $92.8-96.9$ & 100.0 & $47.8-100.0$ & 92.1 & $86.3-96.0$ \\
\hline M. catarrhalis & 100.0 & $39.8-100.0$ & 96.6 & $94.6-98.1$ & ND & ND & 97.9 & $94.0-99.6$ \\
\hline S. marcescens & 100.0 & $54.1-100.0$ & 98.1 & $96.4-99.1$ & 100.0 & $29.2-100.0$ & 98.6 & $95.0-99.8$ \\
\hline S. agalactiae & ND & ND & 96.6 & $94.4-98.1$ & ND & ND & 95.8 & $91.2-98.5$ \\
\hline S. pyogenes & 100.0 & $2.5-100.0$ & 99.6 & $98.5-99.9$ & 100.0 & $2.5-100.0$ & 96.5 & $92.0-98.9$ \\
\hline
\end{tabular}


Table S12. Antimicrobial resistance (\%) to selected agents as determined by routine microbiology

\begin{tabular}{|c|c|c|c|c|c|c|c|c|c|c|c|}
\hline 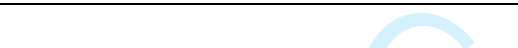 & \multicolumn{10}{|c|}{ Antimicrobial } & \multirow[b]{2}{*}{ MDR } \\
\hline Organism & $\mathrm{n}^{\mathrm{a}}$ & AMC & 3GC & CIP & MAC & METH & GEN & MEM & TZP & GLYC & \\
\hline P. aeruginosa \& Pseudomonas spp. & 79 & - & $21.6^{\mathrm{b}}$ & 17.3 & - & - & 10.8 & 23.6 & 24.3 & - & 20.3 \\
\hline S. aureus & 83 & - & - & 18.9 & 25.0 & 14.6 & 10.0 & - & - & 0.0 & 13.3 \\
\hline E. coli & 43 & 47.5 & 21.4 & 25.6 & - & - & 10.3 & 0.0 & 16.2 & - & 37.1 \\
\hline H. influenzae & 23 & 22.2 & - & 0.0 & 41.7 & - & - & - & - & - & 13.0 \\
\hline Klebsiella spp. & 44 & 30.8 & 20.7 & 10.5 & - & - & 7.7 & 3.3 & 13.5 & - & 15.9 \\
\hline
\end{tabular}

- $\quad$ : Drug inherently inactive against species group

Antimicrobial abbreviations: AMC - amoxicillin/clavulanate, 3GC, third-generation cephalosporin (meaning ceftazidime, cefotaxime or ceftriaxone, as tested), CIP ciprofloxacin, MAC - macrolide (erythromycin and clarithromycin depending on local laboratory), METH - detection of methicillin resistance (agent tested may be cefoxitin, flucloxacillin and oxacillin, depending on local laboratory), GEN - gentamicin, MEM - meropenem, TZP- piperacillin-tazobactam, GLYC, glycopeptide (vancomycin and teicoplanin depending on local laboratory)- MDR - multi-drug resistant, defined as resistant to $\geq 3$ classes according rules described in Magiorakos et al. ${ }^{8}$

${ }^{a}$ Refers to the total number of isolates in the data set. The number tested for any given drug may be fewer.

${ }^{\mathrm{b}}$ Ceftazidime only considered for these species. 
Table S13. Frequency of resistance gene detections by PCR tests among eligible samples ( $\mathrm{n}=606$ for Unyvero, $\mathrm{n}=620$ for FilmArray)

\begin{tabular}{|c|c|c|}
\hline Resistance Gene Target & Unyvero & FilmArray \\
\hline \multicolumn{3}{|l|}{ Carbapenemases } \\
\hline$b l a_{\mathrm{IMP}}$ & 0 & 1 \\
\hline$b l a_{\mathrm{KPC}}$ & 1 & 1 \\
\hline bla $a_{\mathrm{OXA}-23}$ & 5 & NA \\
\hline$b l a_{\text {OXA24/40 }}$ & 0 & NA \\
\hline bla $\mathrm{OXA}-48$ & 0 & 0 \\
\hline bla $a_{\mathrm{OXA}-58}$ & 0 & NA \\
\hline bla $\mathrm{NDM}$ & 2 & 0 \\
\hline$b l a_{\mathrm{VIM}}$ & 3 & 1 \\
\hline \multicolumn{3}{|l|}{$\begin{array}{l}\text { Other genes relevant to } \\
\text { resistance to } \beta \text {-lactams }\end{array}$} \\
\hline bla $_{\mathrm{CTX-M}}$ & 14 & 32 \\
\hline$b l a_{\mathrm{SHV}}$ & 55 & NA \\
\hline$b l a_{\mathrm{TEM}}$ & 20 & NA \\
\hline mecA & 92 & NA \\
\hline mecC & 3 & NA \\
\hline$m e c A / C$ and MREJ & NA & 32 \\
\hline \multicolumn{3}{|l|}{ Miscellaneous } \\
\hline ermB & 68 & NA \\
\hline E. coli gyrA83 & 29 & NA \\
\hline P. aeruginosa gyrA87 & 35 & NA \\
\hline sull & 67 & NA \\
\hline
\end{tabular}

\section{Supplementary References}

1. England PH. Investigation of bronchoalveolar lavage, sputum and associated specimens. UK Standards for Microbiology Investigations: Standards Unit, Microbiology Services, PHE; 2019. p. 1-38.

2. Ozongwu C, Personne Y, Platt G, et al. The Unyvero P55 'sample-in, answer-out' pneumonia assay: A performance evaluation. Biomolecular Detection and Quantification 2017; 13: 1-6.

3. $\quad$ EUCAST. Antimicrobial susceptibility testing EUCAST disk diffusion method. 2019. https://www.eucast.org/fileadmin/src/media/PDFs/EUCAST files/Disk test_documents/2019 manuals/Manual _v_7.0_EUCAST_Disk_Test_2019.pdf.

4. Murakami K, Minamide W, Wada K, Nakamura E, Teraoka H, Watanabe S. Identification of methicillin-resistant strains of staphylococci by polymerase chain reaction. J Clin Microbiol 1991; 29(10): 2240-4.

5. Paterson GK, Larsen AR, Robb A, et al. The newly described mecA homologue, mecALGA251, is present in methicillin-resistant Staphylococcus aureus isolates from a diverse range of host species. The Journal of antimicrobial chemotherapy 2012; 67(12): 2809-13.

6. Harris PA, Taylor R, Minor BL, et al. The REDCap consortium: Building an international community of software platform partners. J Biomed Inform 2019; 95: 103208. 
7. Wootton DG, Cox MJ, Gloor GB, et al. A Haemophilus sp. dominates the microbiota of sputum from UK adults with non-severe community acquired pneumonia and chronic lung disease. Scientific Reports 2019; 9:2388.

8. Magiorakos A-P, Srinivasan A, Carey RB, et al. Multidrug-resistant, extensively drug-resistant and pandrug-resistant bacteria: an international expert proposal for interim standard definitions for acquired resistance. Clinical Microbiology and Infection 2012; 18(3): 268-81. 
